Portland State University

PDXScholar

\title{
The study of national character in the post war era : the work of Erich Fromm, David Riesman, and David Potter
}

Adam Rittenberg

Portland State University

Follow this and additional works at: https://pdxscholar.library.pdx.edu/open_access_etds

Part of the Intellectual History Commons, and the United States History Commons Let us know how access to this document benefits you.

Recommended Citation

Rittenberg, Adam, "The study of national character in the post war era : the work of Erich Fromm, David Riesman, and David Potter" (1988). Dissertations and Theses. Paper 3851.

https://doi.org/10.15760/etd.5735

This Thesis is brought to you for free and open access. It has been accepted for inclusion in Dissertations and Theses by an authorized administrator of PDXScholar. Please contact us if we can make this document more accessible: pdxscholar@pdx.edu. 
AN ABSTRACT OF THE THESIS OF Adan Rittenberg for the Master of Rrts in History presented March 11, 1988.

Title: The Study of National Character in the Post-Wor Era: the work of Erich Fromm, David Riesman, and David Potter.

APPROUED BY MEMBERS OF THE THESIS COMMITTEE:

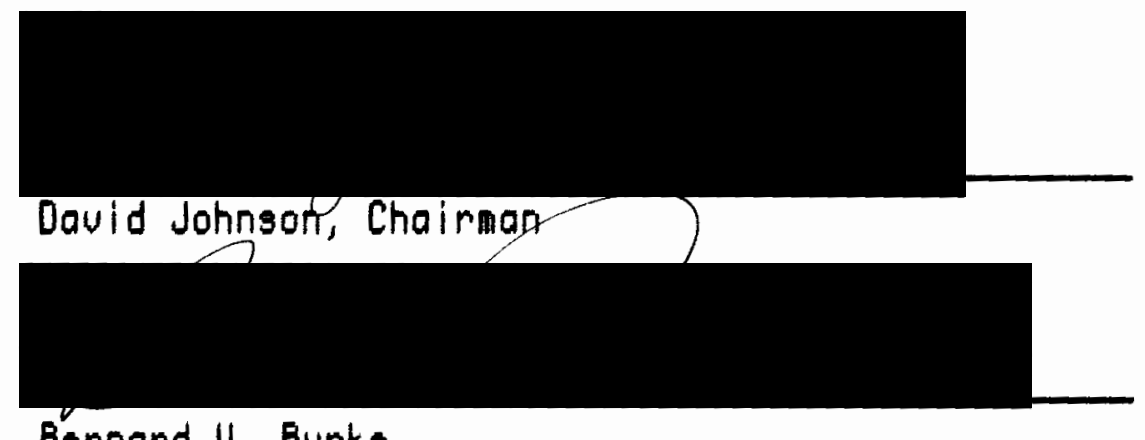

Bernard U, Burke

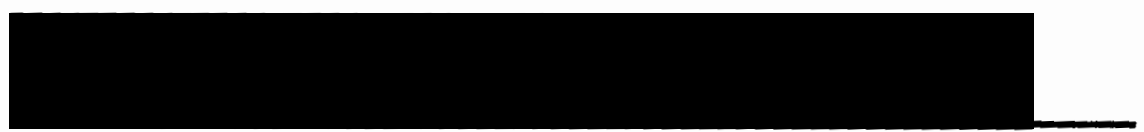

Ann Weikel

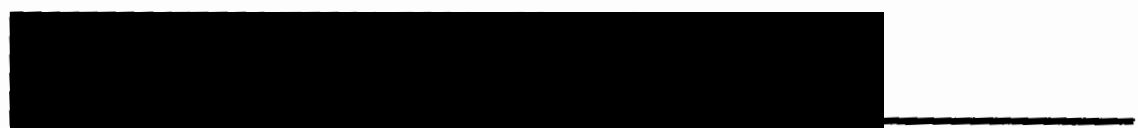

Charles Bolton

Thls thesis examines the study of national choracter through the work of the psychologist Erich Fromm, the sociologist Dawid Rlesman, and the hlstorlan Dould Potter. Above all I Intend to provide a critical exegesls of the three thinkers. I will relate them to one another by discussing the interconnections in their thought, beginning with Fromm's social psychological theory of 
character, turning to Riesman's theory of sociology and, finally, Potter's theory of Rmerican history. Each, I argue, must be studied in the context his time--above all the climate of horror and uncertainty at mid-century.

Froma, a Jew, fled Germany in the 1930s convinced that he was witnessing a decline into a new age of barbarism. Thereafter, he struggled ith the problem of good and evil in a world nakedly evil. Recurrent in his work is the theme of hope in a world beyond hope. Neither world war nor genocide could persuade him to glve up hope and to succumb to pessimist. The task of his social psychology, then, was to explain the trlumph of human lekedness in order to inspire faith in humanity. Hls theory of character did this. He explained human character, the determinant of behavior, as a purely social phenomenon. Thus, he was able to reason that the origins of evil were social. Society, not man, was the source of evil in the world.

From was concerned with the character of modern man which he understood as social character. Remarkably, he did not single out the German character for condemnation in his analysis. He treated It, rather, as a manifestation of wat developing all over the world as a consequence of global socioeconomic development. He understood the rise of Nazism as one consequence of the modern man's conformist and ultimately destructive character.

Froms's social psychology influenced Riesman's approach in his historically oriented inquiry into the faerican character. In many respecte Rlesman's soclology was Fromm's soclal peychology 
Americanized. Riesman's principal concern, however, was not the fate of good in the world but, rather, the fate of individualiom in MoCarthy's Cold War America. By emphasizing individuallsm Riesman departed from the severity of Fromm's social determinism. Riesman's concept of autonomy celebrated individualion and suggested in terms of character the transcendence of time and place, something not inagined by Froma. Riesman understood character as a product of society's influence against which individuals could mount resistance.

David Potter, influenced by Riesman's study of the Rmericon character, pursued the theme of Americanism. Potter's work expresses throughout his self-consciousness as an Rmerican. A Southerner born in 1910, Potter was aware of the contradiction, wore apparent than reai, involved in being both a Southerner and a Fimerican. The idea of character, linked as it was by Fromm and subsequent ly Riesman to socioeconomic conditions, enabled Potter to write about an American character that encompased the South as well as the North. In his work on the American character Potter redefined the historical perspective of David Rlesman. 
THE STUDY OF NATIONAL CHARACTER IN THE POST WAR EAR;

the work of Erlch Fromm, David Alesman, and Dauld Potter

by

ADAM RITTEHBEAG

A thesis submitted in partial fulfillment of the requirements for the degree of

MASTER OF ARTS

in

HISTORY

Port land State Unlversity

1988 
TO THE OFFICE OF GRADUATE STUDIES:

The members of the Comittee approve the thesis of Adam Rittenberg presented March 11, 1988.

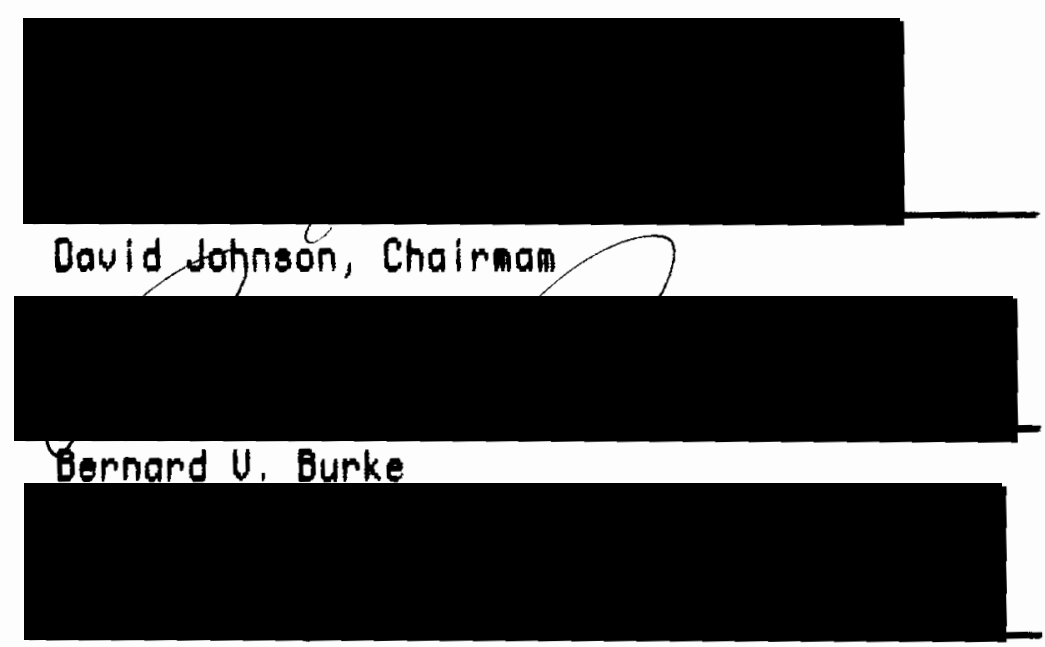

Ann Hoikel

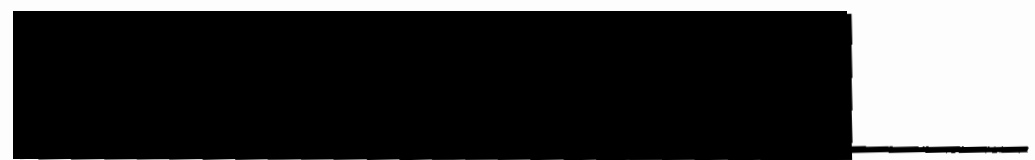

Charles Bolton

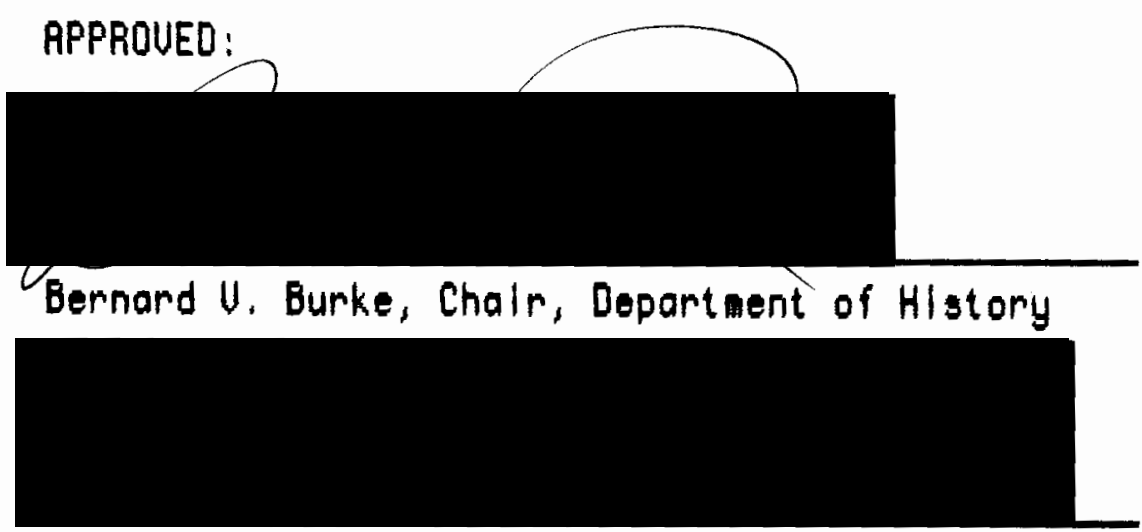

Bernard Ross, Vice Provost for Graduate Studies 


\section{ACKHOHLEDGEMEHTS}

I wish to thank Professor Dauld Johnson for his asslstance and encouragesent. I also vant to express appreclation to the other nembers of adulsory connittee, Professors Bernard Burke, Ann Helkel, and Charles Bolton. 
TRBLE OF CONTENTS

PAGE

ACKNOHLEDGEMENTS $\ldots \ldots \ldots \ldots$ i CHAPTER

I IntRoduction ................. 1

II ERICH FROMM .............. 10

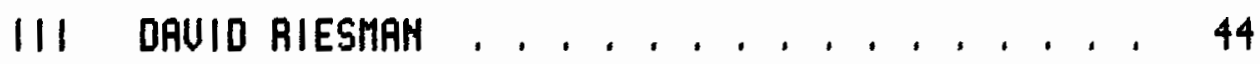

IU DAUID POTTER ................ 32

u cohclusion ................... 96

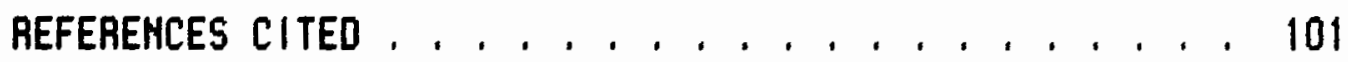




\section{CHAPTER 1}

INTRODUCTION

The study of the nat lonal character was a central feature of post Horld Har. II Intellectual history. It was a project Involuing all of the branches of social science--history, psychology, soclology, anthropology, econosics, and political science. The focus here is on the work of three men--the psychologist Erich Froma, the soclologist Dauld Rlesman, and the hlstorian Douid Potter.

The aodern study of nat lonal character blossoned In the late 1930 s and began to bear frult in the 1940s. Two forces, one Intellectual and other social and polltical, conwerged to make this perlod ripe for the study of nat lonal character. Fros one direction there came an intellectual stioulus that vould carry the study of nat lonal character into the decade of the fortles and beyond. From the other cane a sense of purpose. Intellectually, the 1930s - Itnessed the first graftings of psychologlcal theory onto the anthropologleal study of natlonal character. Morally as well as politleally, the ascendancy of the great dictators, Hitler, Mussolini, and Stalin marked the perlod.

The specter of barbarlsn that hovered over the world, say, from 1935 to 1955 made the study of nat lonal character an urgent 
matter. There was a desire to understand the rise of Mazism, the Second Horld War, the Holocaust, and the Cold Har ith its onnipresent threat of nuclear annihilation. The obuious and understandable need to know one's enewies and one's friends was a key impetus for national character studies. But there were other notives as well. A strand of idealis was involved. Some hoped that a clear understanding of differences in national character would aid the long-term cause of peace anong nations. There was also a feelling in the West that freedom was under siege. How better to deal with the threat of totalitarianisw than to understand the psychology of the masses being convulsed by the times? Prominent anong attempts to comprehend the nature of mass movements was Erich Froma's Escazpe frum Freactin. But there were others such as the

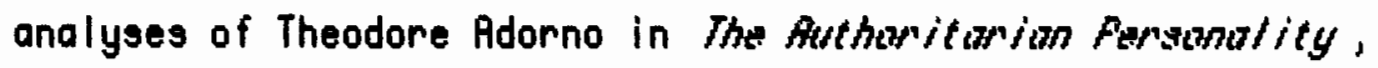
Hannah Arendt in The Gugins of Totalitarizhise, and the American stevedore Eric Hoffer in The True Belieseren. So, in part, the study of national character developed as a response to world crisis.

As Alex Inkles and Daniel Levinson observed, the study of national character stands at the "interface of individual psychology and the social sciences." 1 Traditionally, social anthropologists did nost of the work in this field. Prior to the id-1930s, the study of national character consisted nostly of descript lue studies of social norms and blographical sketches. It was assumed that

IAlex Inkles and Daniel J. Leuinson, "National Character: the Study of Modal Personality and Sociocultural Systems," The Hondhorak of Social faychalagy, 2nd ed, ed, Gardner Lindzey and Elliot Aronson (Reading, Mass: Addison-Llesley, 1969), 418. 
individuals "internalized cultural values," but for the most part "systenatic psychological theory was ignored." 2

By 1934 when Ruth Benedict published futterns af Gultore it was beconing clear, however, that the study of national character was undergoing change. Benedict, applying the concept of "psychological coherence," began looking into the psychological functions of hole cultures and the institutions comprising then. The psychological functions of institutions, according to the anthropologist Geoffrey Gorer, "are the basic data for the analysis of national character." 3 The study of national character assumed that social and cultural institutions affect Individual psychology. Benedict recognized that the institutions of a given culture functioned to the same end, the integration of individuals into society. Though lacking a developed theory of individual psychology, Benedict's work was the foundation of further inquiry into the link between culture and personality. Put simply, national character was understood to be the connection between culture and personality.

The basic problem posed by the study of national character, one left open to endless debate, concerns the degree to which social and cultural factors determine or condition the personalities of people. This shared personality that constitutes national character has been called a number of things, such as "social character,"

2lbid, 419.

3Geoffrey Gorer, "National Character: Theory and Practlce," The stcuty of Culture at a llstance, ed., Margaret Mead and Rhoda Metraux (Chicago: The University of Chicago Press, 1953), 66. 
"basic personality," and "nodal personality." I ill use the tern "social character" because From, Riesman, and Potter did. The study of national character presupposed that people acquire in comon a distinctive personality according to the the and place of their birth. To the extent that national, social, and cultural boundaries overlapped, national character was "social character." States which were conglomerations of nationalities such as the Souitet Union and Yugoslavia caused problens for this sort of analysis. Also, the idea of national character tested the notion of an American "nelting pot." Does a nation of imigrants such as the United States acquire a distinctive character? I believe that the assuaption of an American character proved fruitful.

The work of From, Riesman, and Potter form three stages of a chapter in the story of the pursuit of the American character. Riesnan and Potter in particular ade direct and significant contributions to this inquiry. I begin with From because his psychological theory of social character and his characterization of modern western man underlay Riesman's study of the Rmerican character. Potter's work, in turn, developed from Riesnan's.

Erich From had a significant influence upon the development of national character studies. He, along with others such as Abran Kardiner and Ralph Linton, developed theories of individual psychology that stressed enuironmental over biological factors and served as the foundation for national character studies. Fromn's definition of "social character," however, was stricter in terms of culture-personality nexus than either Linton's concept of "nodal 
personality" or Kardiner's concept of "basic personality. "Frome understood social character as a social necessity. Society required a certain type of character in order to function properly, and thus deviation from an established norn suggested social dysfunction. Linton's use of the the statistical concept of node, as Inkles and Levinson noted in their concise sumary of the study of national character, took into account the possibility of variety anong individual personalities and "patternings in any society." 4 it seens as though the existence of several statistically relevant personality types in a society would discount the very existence of a "national" character for that society. Likewise, Kardiner's idea of "basic personality" referred to the type of personality that was "nost congenial to the prevailing institutions and ethos of the society." 5 Thus in his understanding of social character as a functional prerequisite for a society from carved out a distinct position.

On the basis of his understanding of social character, Fronn conducted a broad inquiry into the character of western san, believing that there as a consistent pattern of social and econonic development throughout the Hest. His concern was always the plight of western wan. Modern psychology, according to From, revealed the central inportance of "interpersonal relationships" in the formation of personality, and the study of the social basis of personality (the study of character) inferred personality fron behavior. From

\footnotetext{
4 Inkles and Levinson, 424.

5lbid., 424.
} 
distinguished between the social and the biological areas of personality. He was concerned only with the social part of personality, and he discounted the iaportance of other aspects of personality. He labeled the social side of personality character, and he believed that behavior was reflective of character. From devised several character orientations in order to show how different sorts of behavior were reflective of different characters. From belleved that by understanding how people related to others and also the world one learned about their character, that is who, essentially, they were. In terms of human conduct character, and character alone, was for From ethically significant. Thus From believed that the troubles of the world had social origins. It followed then that the source of man's problens was the organization of his society, and From thought that psychology applied to the task of social organization could solve man's problens. At the time From was oriting the problems confronting wan were war and genocide.

The beginning point of From's "science of man" was his understanding of hunan nature, which he presupposed was "characteristic of the human species." Neither fixed nor infinitely nalleable, human nature, he held, was adaptable. In retrospect it seens also to have been benign and ineffective. Man was a naturally good creature living in a dreadful world. But out of the necessity of having to adapt, man had become dreadful as vell. From went on to distinguish between virtuous and vicious characters as well as sane and insane socletles, distinctlons based upon his understanding 
human nature. His only hope for the future was a transfornation of the world. Paradoxically, it seens, man the victin was to becone the shaper of a new world. Throughout, the subject of Fromin's inquiry was "man," and his enphasis was upon the urgency of his dilenna.

David Riesnan was are interested in the plight of individuals than of mankind. Autononous individuals were his heroes; and as Riesman lagined then, the autonomous were beleaguered in the nodern, corporate, bureaucrat ized world of the twent leth century. $A$ desire to understand his own times led David Riesman to contrast today's Americans to those of yesterday. Like Froma, however, he believed that Americans could be understood along the same lines as other western peoples. This broader analysis was, in retrospect, alsost superfluous to his handling of Anerican character. Thus 1 regard his work as essentlally a study of the American character.

The perception of a difference between what history told his about past Americans and what he saw in his contemporaries inspired Riesman's study of the Rmerican character. Fromian psychology, by linking character to social structure as it did, provided Riesman wth a way of explaining differences he perceived between twent iethcentury Anericans and their nineteenth-century counterparts. Riessan was able to link the transformation of American society to the development of the American character. In oun, the differences between America as an industrializing society and Anerica as a consuner society spelled out the changes in the American character. The change in the American character from "Inner-directed" to 
"other-directed" paralleled the transition of America fron a society of production to a society of consunption. The point of reference for hinself as vell as his critics in his discussion of the American character was Alexis de Tocqueville, who from Riesman and others gained much currency in the 1950s. The revitalization of Tocqueville during this period sas natural, given intellectuals' heightened concern with the Anerican character. The thene of the American character, though it stretched back beyond Tocqueullle to Crevecoeur, was rooted in the former's discussion of Aenchackisy in Amesico during the age of Jackson.

Aiesman's insightful descriptions of the Aaerican character at nid-century influenced David Potter. Beginning with Riesnan's sketch of the twentieth-century national character, Potter sought to uncover its historical roots. He examined nore closely the nilleu in which the Anerican character developed and elaborated upon Riesnan's historical perspective. Potter, too, harkened back to Tocqueville, eaphasizing abundance as a factor in the formation of Anerican character. His thesis was that the Anerican character had been conditloned by aterlal plenty. Living in a spacious and bount iful enviromment Americans had developed at titudes and institutions that betrayed the luxury of living in a land of plenty. Americans, according to Potter, equated freedon and equality with opportunity. Americans cherished the opportunity to get mealthy as a birthright, and, he said, they did so at the expense of other values. Americans sacrificed security and the sense of belonging that cones with assured status in order to pursue their personal 
fortune. They were outwardly conforwist and inwardly distressed.

Like Riesman's other-directed character and Fromn's consuner oriented character, the sodern Rmerican in Potter's estination was lonely and anxious.

Three chapters follow. Chapter one discusses Froan's psychology and his study of character. Chapter two addresses Riesman's analysis of the American character. Chapter three deals with Potter's interpretation of the Raerican character, I end with a conclusion about the place of their work in history. 
CHAPTER $\|$

ERICH FROMM

Erlch From spent hls llfe trylng "to understand the laus that govern the llfe of the Indluldual man, and the laws of society-that is, of men and their social existence." 1 in his approach he was part cassandra and part pollyanna. He described a present - ithout hope while he anticipated a future olthout despair. It is as though he illed optialsm in order to escape hopelessness, as though he wos conulnced that by refusing to concede reality he could alter reality. He was conulnced that reality was oretched and modern man's existence insane, yet he placed man beyond reproach and belleved hil capable of perfection. At the center of Froman's work was this conflict between pessinisn and opt laisn. The urgency of his message arose out of this conflict. The pessinist told his readers they were dead onile the opt laist Insisted they could overcome death, 2 Thus to understand From one nust realize that his

Thainer Funk, Enich Froms: The Courage to be Human, with a pastsoript by Erich Frose (New York: The Cont inuun Publishing Company, 1982), 3, citing Erich Fronn, Beyzond the Chains of lllusion: My Encountar with Marx and Frewd (New York: Simon and Schuster, Credo Series, 1962), n.p.

EErich Fromm, The Sane Society (New York: Alnehart \& Company Ine., 1955), 360 . 
thought was strung taut between two profound convictions, the ugliness of human existence and the sublinity of human nature. Sonehow Fron was able to disassociate the ghastly design from its architect and conden society while lavishing wan with praise. His analysis of the relationship between nan and society developed around this good man-evil society paradox. Rs psychologist, sociologist, philosopher, and crusader From sought to understand life's tragic experiences, to discover meaning in an age absorbed in the absurd, and most importantly to resolve the conflict between good and evil in favor of the good.

His anbition was no less than to save humanity. This is evident in his three nost widely known books, Escappe fras frepedas

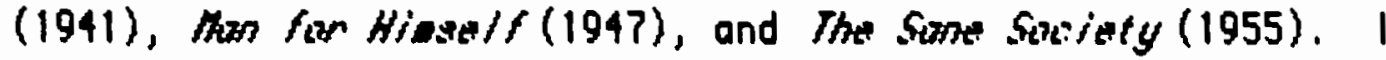
believe that the three books explore the sane themes and elaborate a consistent philosophy. Therefore, I treat then as pieces of a larger work which offered a penetrating analysis of the problen of evil in the modern world. Psychology was Fromn's tool of analysis. Psychology, he argued, could explain the nature of evil and ap the way to a world beyond evil. Escapos Fram frowation analyzed what From perceived as modern man's hostility to his nesly won freedon from the arbitrary rule of kings. With freedon cane frightening responsibilities. Duerwhelmed by anxiety, man, From believed, was retreating into authoritarian systens. Plainly, From was confronting the nightmare of Nazi Germany. Though he left Germany in the 1930s, it sas inpossible for him, a Jew, to shut out the nacabre vision of Mazisn. The book tried to explain the 
socioeconomic origins of modern man's conformist and ultimately destructive character which he belleved nas responsible for the slaughter of illions and the destruction of civilization. In one sense Escaupe frow fresection can be understood as an account of how good nen comit genocide, perhaps even as an apology for good wen who perpetrate evil.

Of course it was never from's intention to orite apologetics, but it seens to have been inherent in the paradox of good men in an evil society. Six years after Escape fras Freedon he published Han for Hinself. This book explained in greater detail the nature of the human self and offered a more complex analysis of the corrupting effects of soclety. Here From developed fully the link between man's psychic needs and socioecononic structures in the formation of character. He also presented the humanist alternative, a philosophy of llfe attuned to basic needs of the self.

The sane society, finally, presented a socioecononic olternative to both bureaucratic capitalisn and bureaucratic communisn. From proposed a new order built upon the ideals of humanise, a community structured around the "Golden Rule." The society he envisioned was sane because it cotered to man's psychic needs and thus ended the distortion of human nature by society. Mon would be one with himself and sane. Man would flourish in a condition of love, freedom, and justice. The sane soclety would const itute the fulfillment of humanist ideals inspired by biblical prophecy. His humanis was rooted in the religion of his youth, Judaisa. 
Life began for Erich Fromm in Frankfurt am Main, Germany in 1900. His parents were Orthodox Jews, and he was a precocious child who began to study the principle texts of Judaism, the Old Testament and the Talmud, at an early age. The hopeful prophecies of Isaiah, Amos, and Hosea in the Old Testament made a lasting impression on him.3 In the aftermath of the First Horld Har he encountered Marx whose secularized messianism had a great influence as well, particularly in regard to his interpretations of history and religion. Marx, according to Bernard Tauber and Edward S. Landis, provided "the key to the understanding of history and the manifestation, in secular terms, of the radical humanisn which was expressed in the messianic vision of the Old Testament prophets." 4 From studied briefly at the University of Frankfurt, and in 1919 moved to the University of Heidelberg where he studied under Alfred Weber, the sociologist and philosopher of history, Karl Jaspers, the existentialist, and Heinrich Rickert, the neo-Kantian philosopher.

After receiving a doctorate in philosophy in 1922 for which he wrote a dissertation on "the sociopsychological structure of three Jewish Diaspora communities: the Karaites, the Hasidim, and the Reformed Jens," From moved to Munich where he studied psychiatry and psychology. He remained in Munich until 1930. There occurred two particularly significant monents in his intellectual

3 Funk, Eniah Frane, 1-9. Unless otherwise noted all blographical information for Fromm comes from this source.

"Bernard Tauber and Edward S. Landis, "On Erich Froma," In the Nane of Life, Esarogs in hanar of Emiah Framen (New York: Holt, 1971), xi. 
development. First, he cane in contact with Buddhist phi losophy which inpressed his with its combination of mysticisn and rationalisn. Second, he read Johann Jakob Bachofen's sociopsychological study of patriarchal and satriarchal societies hather fight which suggested to hin, contra Freud, the prominence of social and cultural forces in the shaping of personality.

In the 1930s From left Germany in order to escape Mazisn. He arrived In the United Sates in 1934. He was employed as a professor of psychology at various universities and institutes around the country and established a worlduide reputation as a "neo-freudian" psychologist, utopian social critic, and humanist philosopher. In 1949 he noved ith ife Annis to Mexico on the aduice of her doctor. Thereafter, he divided his time between Mexico and the United States until his death in 1980. His professional life was devoted to developing a workable synthesis of psychology, philosophy, and sociology. The product of this synthesis was a social psychology grounded in a humanist view of the world. It was a mix of rationalis and asticisn with strong doses of Marx and Freud.

One of his biographers, Ranier Funk, has shad light on the crucial role of Judais as a source of From's thought. The influence of Judais is particularly interesting because from abandoned the practice of conventional religion in his aid-twenties and thereafter espoused what Funk has termed "religlous humanisn." ficcording to Funk, Froms's later thought reflected his early exposure to two traditions of Jewish thought, rationalisn and ayst icisn. Two thinkers, Moses Maisonides and Hermann Cohen, 
figured prominently in Fromm's encounter ith Jewish rationalian. From was influenced greatly by the negative theology of twelfthcentury philosopher Maimonides. 5 Taking the ban on images as absolute, Maimonides denied the possibility of positive knowledge of God and maintained that descriptions of God were really only descriptions of God's effects. Knowledge of God's effects was supposed to lead man to perfection. God's conduct was supposed to be the model for human conduct. As Maimonides wrote in his fivide af the Fenplaxid,

the chief ain of man should be to make himself, as far as possible, sinilar to God: that is to say, to make his acts sinilar to the acts of God, or as our Sages express it in explaining the verse, 'Ye shall be holy': 'He is gracious, so you also be gracious; He is merciful, so be you also merciful, ' 6

In Malmonides, therefore, the important questlons of religion, of the idea of God, thus become ethical questions in the Jewish tradition.

Also Important to Fromn's understanding of Jewlish rationall sin was Herwann Cohen, who in the nineteenth century Infused Maimonides

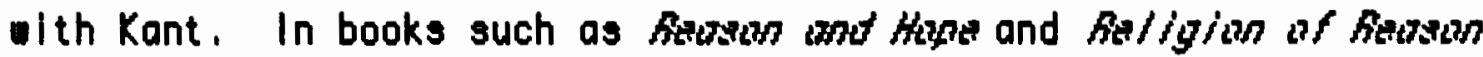
Cohen argued that the essence of religion was morality. For instance he wrote in Starsan and thats. "Ethics would be demeaned and religion obscured if God's significance were to be found beyond the

\section{Funk, Erich Frose, 183-94.}

Glbid., 186, citing Moses Maimonides, Guite af the Ferp/exed, trans., M. Friedlander (New York: Hebrew Publishing Company, n.d.), 198. 
realm of morality. The ethics intrinsic to God's nature, and that alone, constitutes religion in Judaisn." ? The terms religion and morality vere, in fact, interchangeable, and religious knowledge, knowledge of God, was knowledge of God's moral attributes. In the tradition of Kantian rationalisn Cohen interpreted religion as a construct of reason. Cohen argued that the idea of God was essential for the existence of a moral order. Therefore, the existence of a moral order affirmed the existence of God. Cohen's conception of religion as a "religion of reason" went a step beyond Maimonides' view of religion as "revelation understood by reason. " 8 From went one step further than Cohen and excised God from religion. Cohen linked the existence of a moral order known only by reason to the existence of a "transcendent" God, an absolutely noral ideal. Fron Fromn's humanist perspectlve the logic of Cohen's rationalist theology negated God. Rather than affirm God, human reason affirmed the power of man. In a sense man became God, and the question of relationship between man and God dissolved into unity.

The unity of God and man existed also as a theme in the tradition of Jewish mysticisn. Thus the rationallat teachings of Maimonides and Cohen aingled in From's ind with aysticism. He encountered Jevish mysticisn while a student at the University of

Plbid, 189, citing Hermann Cohen, Reusun and Hope: Selections froe the dewish Uritings of Hernoun Cohen, trans., Eua Jospe (New York: H.W. Norton \& Co., 1971), 221.

Bibid, , 188-94. 
Heidelberg. Under the tutelage of the socialist Schneur Salman Baruch Rabinkow, From absorbed the teachings of Rabbi Shneur Zalman, who in the eighteenth century established a reform movenent -ithin traditional Hasidisa called Habad Hasidism. Hasidisn vas essentially Kabbalise with deenphasized nessianisn. According to Kabbalist teaching the achievenent of unity between God and man was completed by God. According to Hasidisn it sas not. Funk has oritten that in Hasidisn "the ethical and the religious spheres are brought into unity by man's sanctification, which is based on the idea that it is through man's action that creation is perfected." 9 In Hasidisn, as in Kabbalisn, God and man were united through the nediation of the Zaddik, the "devout individual." Habad Hasidisn, hovever, rejected the role of the Zaddik as the learned spiritual leader in favor of the benoi, the "average man." The benoi, equipped with reason, could achieve sanctification. Put siaply, Habad Hosidisn denocratized Judaisn, and nade God's grace readily available to all.

Kabbalisn also taught that man possessed two souls, a divine soul and an aninal soul. Hasidisn and Habad Hasidisn retained this bellef. In Habad Hasidisn it was believed that reason was sufficient for unraveling the mysteries of the divine soul through study of the Torah. The object of reason mas to acquire knowledge that enabled an to laitate Gad and thus share in God's divinity. The aninal soul was associated ith evil, and importantly, euil

9lbid., 198. 
represented in Jewish oysticism, according to Funk, "a secondary phenomenon." In his essential nature man was good. The idea of evil as a secondary potentiality was a central feature of From's thought.

Funk has described Habad Hasidiss as "nystical psychology, "10 that is the study of the divine soul by reason. Froms's belief that the human soul was subject to psychological inquiry seens by implication to have had its source in the "nystical psychology" of Habad Hasidisn. Despite the fact that Fron did not refer to Jevish mysticism as a source of inspiration for his humanisn, Funk has denonstrated an iapressive number of parallels between Froma's "religious humanism" and Habad Hasidisa. In addition to the distinction between primary and secondary natures and the idea that the husan soul was comprehendible by psychology, Froms's belief in human self-perfection, as well as his naturalisn, appear to have have had their origins in Habad Hasidisn. Fromm's humanisa, however, had a different center for its faith than did Habad Hasidisn. The latter revolved around a belief in God while the former a belief in man. 11

From substituted religious humanisn for thelstlc bellef. One an replaced one God. Funk has explained that Froan's concept of religlous humanise was drawn from Marx. In his Easmanis: and Philosophlaol Honuseripts of lB44 Marx wrote that "the question of

10lbid., 203, citing Gershon Scholen, Mojor Trends in dewish Mysticist (New York: Schocken Books, 1954/1961), 341.

11/bid, 204. 
an alien being, a being above nature and man--a question wich implies an adaission of the unreality of nature and of man--has becone imposslble in proctice."12 From, follouing Marx, rejected theonony outright as a contradiction of belief in human autonony. Unlike Marx, however, From did not see religious belief merely -ithering away as man escaped his socloeconomic bondage. Contra Marx, From understood religious belief as answering a hunan need for an object of orientation and devotion. Consequently, From saw humanisn transcending theistic belief. Theistic belief existed historically as a comprosise between man's religious nature and irroligious society. Man, From wrote, "longs for a world in which love, freedon, and justice are rooted, and since such a world does not exist, he creates a separate institutions alongside society, religion."13 In From's religious humanisn man was to be his own object orientation and devotion. Soclety, in turn, would become the realization of nan's highest aspirations. Hunanisn ouercane the separation of the celestial city of God from the the terrestrial

\footnotetext{
12lbid,, 215, citing Karl Marx, Eorly Uritings (Mew York: Uintage Books, 1975), 357.

13Erich From, post script to Enich Fraes by Rainer Funk, 29495. From believed that his ulew of religion was essentially the same as Marx's: "For hin, religion was an opiate for man because it tries to sat isfy his profoundest needs by lllusions instead of allowing hla to pluck the lluling flower. Marx was not antireligious. He was profoundly religious and not an eneny of 'religion' for that very reason." From believed that since Marx interpreted religion socioecononically rather than psychologically, his humanisn is isunderstood as antireligious (Eriah Frans, 21316).
} 
city of man, between religiaus principle and earthly reality. Man, no langer torn between God and Mammon, would becone like God.

The rejection of theonony and a belief in hunan self-perfection were the fountainheads of From's psychology. Understanding man as his oun object of opientation and devotion was its objective. He believed that psychology probed the depths of man's nature. He was convinced that he could show how man had degenerated into a lower, brutish form of life and how man could be reborn into a higher, divine form. The purpose of Escoupe frue Fratudize was, from urote, "to analyze those dynanic factors in the character structure of modern man which made his want to give up freedon in Fascist countries and which so idely prevall in aillions of our own people."14 From was concerned with the dangerous inplications of the character structure of nodern man. For From psychology was built around the analysis of character. The question of understanding From's peychology, therefore, becones one of understanding what he seant by character.

In the most siaple terms character determined how individuals got along in the world. The function of character in the human world was analogous to the function of instinct in other animals. From thought of character as "the human substitute for the inst inctive apparatus of the aninal." 15 People were not born with

14Erich From, Escope Enan Fresodon (Hew York: Rinehart \& Company, Inc., 1941), 6.

15Erich From, Mon for Himself (How York: Rinehart \& Cospany, Inc., 1947), 59. 
character. Instead, they acquired it as they satured. Character was only one part of personality. Frome understood personality to be "the totality of inherited and acquired psychic qualit les which are characteristic of one individual and wich make the Individual unique." 16 in essence From divided personality in two. On one side were those psychic qualit les acquired socially which comprised character and on the other those inherited biologically. Character was all important to From because differences in character constituted "the real problens of ethics" while biological factors such as teaperanent held "no ethical significance."1?

Whether correct or not Fromes distinction between the ethically significant and insignificant portions of personality was cruciol to his argunent. Since he intended to preserve the dignity of man, he needed to keep the focus on character and thus society as the root of evil in the norld. "The virtuous or the vicious character," From orote, "rather than single virtues or vices, is the true subject of ethical inquiry. "18 He belleved that since character was acquired after birth through social interaction virtue and vice had wolly social origins. He thought that by linking ethics to character he was in a position to show how man may decide for hiaself whether he is living rightly or orongly.

From was convinced that a thorough understanding of character would enable man to ascertain the good life. To put Fron's view of

16/bid., 50.
17lbid., 50.
18/bid., 33. 
character in perspective it is helpful to contrast hin to Froud. From thought of his theory of character as a "dynanic" alternative to Freud's "static" theory. Furthermore, he sav his theory as an - laboration of Froud's initial insight into the importance of character. According to From, Froud had been the first to recognize the complex relationship between behavior and character. Froud had showed that wile behavior was a manifestation of character, it did not irror character. In Fromn's sords "Freud developed not only the flrst but also the most consistent and penetrating theory of character as a systen of strivings which underlie, but are not identical eith, behavior."19 For Instance, courageous behavior could have been a consequence of a number of notivations, a desire for fame or an urge toward suicide to name two, but courage itself was not to be considered a character trait. From believed that Freud had erred when he located the source of the strivings, wich go to make up character, in the libido.

From made a succinct exposition of the difference between Freud's "biologisn" and his oun "social psychology."

Freud's essential principle is to look upon man as an entity, a closed systen, endowed by nature with certain physlologically conditloned drives, and to interpret the development of $\mathrm{hls}$ character as a react lon to sat is fact lons and frustrat lons of these drives; whereas, in our opinion, the fundanental approach to human personality is the understanding of man's relations to the world, to others, to nature, and to hinself. He belleve that man is prlmarily a social being, and not, as Freud assumes, prinarlly self-sufficient and only secondarily in need of others to sat isfy his instinctual 
needs. In this sense, we belleve that individual psychology is fundanentally social psychology, or in [Henry Stack] Sullivan's terns the psychology of interpersonal relationships; the key problen of psychology is that the particular kInd of relatedness of the indluidual to the world, not the satisfaction of single Instinctual desires.20

From revised Freud's explanation for Irrational behavior and claimed that he had istaken "the causal relation between erogenous zones and character traits for the reverse of what they really are. -21 From thought that erogenous zones were useful netaphorically, not diagnostically. Take for example the "oral" person. According to From, he was a passive recipient of the world around, possessed of "the desire to recelve everything one wants to obtain--love, protection, knowledge, naterial things.,. 22 This type of person would often drean or fantasize about being fed, nursed, or otherwise orally stinulated. Freud concluded that such a person suffered from an "oral fixation" and that his fixation had resulted fron excessive oral stimulation or deprivation during childhood. "Oral fixation," according to From, was a particularly apt vay for the individual to express his "receptive orientation" to the world. Likevlse, where Freud understood "anal" behavior traits such as obstinacy, orderliness, and aloofness to arlse from a childhood fixation on the anus, From saw such a "fixation" as an expression of an orientation to the corld he called "hoarding". Fromen's difficulty with Freud's position arose chiefly because Freud

$$
\begin{aligned}
& 20 \text { lbid., } 290 . \\
& 21 \text { lbid., } 291 . \\
& 22 \text { lbid., } 291 .
\end{aligned}
$$


did not satisfactorily explain social and cultural patterns of behavior. From criticized Freud's theory, by noting that

as long as we assune, for instance, that the anal character, as it is typical of the European lower class, is caused by certain early experiences in connection with defecation, we have hardly any data that lead us to understand why a specific class should have an anal social character. 23

It is Important to point out that Freud's perspective lent itself to dark views of human nature and human destiny. In Civilization and lts Disciantents (1930) Freud argued that the demands of human nature and soclety were at odds. Apart from society man was a savage, within he was neurotic, lonely, and desperate. The building of a civilization, according to Freud, proceeded upon the suppression of instinct. 24 Froma's view of human nat ure was irreconcilable with Froud's. When they looked inside man they saw fundamentally different beings. Freud saw a seething libido and From something beautiful which he terned the self. From rejected Freud's theory of "instinctual orientation" because he could not accept its conclusion. Freud's vieu led to a "profound conviction of the eickedness of human nature." 25 The disagreement between the two men was over the nature of humankind.

Fron did not really reject instinctual theory conpletely. He identified one human instinct. Froma's wan was born with a benevolent inclination to get along in the world. For Freud

23lbid., 293.

24sigmund Freud, Civilization and /ts Discant onts (Hew York:

H. H. Morton, 1961), 44.

25Frome, Escope froe Freodon, pg. 294. 
character was essentially a well or 111 trained libido. For Froma It was a nurtured or abused self. Fromn's theory of character presupposed the good nature of man. Don Hausdorff has described Frome's conception of the "self" as "the cornerstone of social character." Hausdorff has noted that "logically, the critlcs who are unconvinced about Fromn's conception of the self believe, as a consequence, that his whole theoretical structure collapses." 26 Fromn's harshest critic, John Scharr, charged,

The concept of the self as a substance, a notion which for centuries had been the strongest of fspring of the metaphysical reason, was exposed by Hume as a bastard of confused and fevered inagination. Slnce Hune's exposure, the self has never been restored to full philosophical legitinacy, 27

Scharr questloned the philosophical legit hacy of Fromn's humanism, arguing that Froma's theory relled upon already discredited ideas in philosophy. From's formulation of the self, he mrote, "rests upon a pre-Hunean conceptlon of the self as a simple substance and upon an Aristotelian conception of potentiality as something inherent in nat ter. "28 Does From have a meaningful conception of the self?

Fromm's understanding of the self was more spiritual than metaphysical. For From the self represented human nat ure. The self was an article of faith for his, and he was convinced of its nobllity. He deferred to the authority of Aristotle and of Spinoza

260on Hausdorff, Erich Frame (Hew York: Twayne Publishers, 1972), 47.

27 John Scharr, Escope inan Authority, 66. 28 lbid., 68. 
in the formulation of what he called a humanistic science of man.29 From revived something akin to Aristotle's idea of final-cause. Aristotle had oritten, "Hature, like ind, always does whatever it does for the sake of something, which sonething is its end."30 Hature pursued an end, its end being its final cause. From shared -ith Aristotle a teleological vien of hunan nature and urote, "From the nature of man, Aristotle, deduces the nors that 'virtue' (excellence) is 'actluity, 'by which he means the exercise of the functions and capacities peculiar to man." 31 Spinoza had defined virtue as "preserving one's being" and preseruing one's being as beconing what one potentially is. From concluded that "virtue is the unfolding of the specific potentiallties of every organisn; for man it is the state in which he is nost human. "32 Man would be most human when he had fulfilled hingelf or as Funk orote, perfected creation. From belleved that the modern way of life was a perversion of creation and that mental IIIness was the consequence. He sau sodern man's destructive and conformist character as evidence of his sickness. His judgment of the human condition depended on

${ }^{29}$ Froma, Man for Hiaself, 25-30. Bertrand Russell reported that Mainonides is regarded as an important source for Spinoza. This supports circunstantially Funk's argument that Mainonides influenced From since he acknowledges his indebtedness to spinoza. A Histary of Western Philosophy (Meo York: Simon and Schuester, 1946), 423.

30 Encyclopedia of ahilosophy, 1972 ed., s.u. "Psychology" by R.S. Peters and C.R. Mates, 3.

31 Froma, Mon for Hiesself, 25.

32 Ibid., 26. 
his ability to determine what man actually was and what his needs were.

Hume had contended that perceptions were distinct and ephemeral and that it was not possible to establish connections anong then, and, therefore, that the idea of a human self as a unity was fallacious. 33 He described the self as nothing other than a "bundle of perceptions." From was suggesting on the other hand that belief in the human self was not unfounded. The progress of psychology lay, he wrote,

in the return to the great tradition of humanistic ethics which looked at man in his physico-spiritual totality, believing that man's aim is to be himself and that the condition for attaining this goal is that man be for himself. 34

From believed that the study of unconscious motivation, which Freud had revolutionized, had established the groundwork for a phllosophical revolution. "The drive to live is inherent in every organism," he srote, "and man cannot help want ing to l lue regardless of what he would like to think about it "35 Psychology revealed the nature of this inherent orive for life and thus was able to make distinctions between normal and abnoraal psychological development. What was conducive to normal development was good and what was conducive to abnormal development was bad. He did not express a factual understanding of the self, and he was guilty of suggesting

33 The Enayclapedia af Fhilasanhy, 1972 ed., s.v. "Psychology" by A.S. Peters and C.A. Mace, 13-14.

34Frome, Man for Himatf, ?.

35 lbid., 18. 
that he had evidence when he had none. Thus he left hinself open to criticisns such as those made by Scharr. From would have been better off if he had avoided the issue of a metaphysical self, but his failure on this count was not fotal. Faith is secure without metaphysics, and the whole of Fromn's thought rested upon the presupposition that eull acts were abnormal and contrary to human nature.

From dree his conception of human nature, of the human self, from his estimation of man's existential condition. From claimed to understand man's existential needs. In Mon for Hiasedf he introduced the idea of existential needs, and in the sone sireitery he developed idea fully. Five existential needs predominated. There were needs for relatedness, transcendence, rootedness, an experience of unity, and an object of devotion,36 Existential needs were consequences of what From termed "existential dichotomies," and man experienced them because of who he was. From called wan "the freak of the universe." "Self-avareness, reason, and Inagination," he suggested, "have disrupted the 'harmony' which characterizes animal existence. Their energence had made man into an anomaly, into the freak of the universe."37 The simple fact that man was aware of his oun existence inuited problens not experienced by other animals. He argued that man was confounded by two existential contradictions. First, consciousness haunted nan. Since man was awore of himself, he was also anare of his mortality. The fact that throughout Ilfe

36from, The seme sersiety, chapter 3.

37From, then for Hissed/, 40. 
man could anticipate death, From belleved, forced wan into accepting defeat for hisself. The second existential dichotony was dependent on the first. Because death was iminent, man realized that he could not accomplish what his birth set him forth to do. "Man's life," he orote, "beginning and ending at one accidental point in the evolutionary process of the race, conflicts tragically - ith the individuals clain for the realization of all of his potentialities."38 From was arguing that the facts of existence engender fatalisn. A person could not hope to accoaplish all that he was capable of achieving. To do so his lifespan would have had to equal that of humanity.

To draw the meaning of existential dichotonles more clearly, From juxtaposed then to historical dichotonies. Historical dichotonies referred to the problens of history that were man-made. He considered instances of man's inhumanity to man in terms of historical dichotonies. Historical dichotonies posed special problens for man, but they were solvable unlike existential dichotonies. Because they vere often confused with existential dichotonies, Frome felt that problens with solutions went unresolved. The seeds of cruelty were not planted in human nature. Rather, as he wrote in Escope fros Fresolos, "the nost beautiful as well as the nost ugly inclinations of man are not part of a fixed 
and biologically given human nature, but result from the social process which creates wan. " 39

From's message was that man could not be indifferent to his oun fate. He was convinced of the oneness of man. "One Indiuldual," he declared,

represents the hunan race. He is one speclfic example of the human species. He is "he" and he is "all"; he is an individual olth his peculiarities and in this sense unique, and at the same tine he is representative of the all characteristics of the hunan race. His individual personality is deternined by the peculiarities of human existence common to all men. 40

From devised a noral philosophy prenised on his belief in the unity of nan. Egolsn and solipsisn were inpossible. "Love of others and love of ourselues, he orote, "are not alternatives, "41 Thus, following Aristotle and Spinoza, he offered what he terned as an "objectluist" approach to the problen of self-Interest. He equated "seeking one's proflt" with "virtue" and turned the problen of ethics into one of ascertaining what self-interest really was. "It follows," he contended,

39From, Escope trase Froedon, 12. At this stage in his work From had not developed the ldea of exlstentlal needs. He belleved that man had only physiologleal and historical needs. Because he was not thinking in terns of moral philosophy, existential needs were not essent lal to his argunent. When he becane concerned with humanist philosophy he encountered a problen of objectivity. He solued this problen by postulating human nature as his source of objectivity. The idea of man's existential self and its needs thus becane crucial.

40 From, Hon fon Hiesself, 44.

41 lbid., 129. 
that man can deceive hinself about his real self-interest if he is ignorant of his self and its real needs and that the science of man is the basis for determining what constitutes man's self-interest, 42

The "real needs" of the self were those which produced harmony. Man was to "seek his own profit," his profit being synonymous with the profit of others. Kant's connand to "act so as to treat humanity, whether in your own person or in that of another, always as an end and never as a means only" puts in a phrase what Fromm means by "seeking one's own profit." Kant would have objected to the idea of basing an ethical system on the principle of "seeking one's own profit," but From echoed Kant's opinion that individuals be viewed almays as subjects not objects, as ends not means, 43

From belleved that the insights of psychology valldated his opinion of self-interest, and he produced a corollary to the "Golden Rule": "Whatever you do to others, you also do to yourself". "To violate the forces directed toward Ilfe in any human being," he explained, "necessarily has repercussions on ourselves." 44 This article of faith derived directly out of a belief in the human self, a belief in the goodness of the human soul steeped in the Jewish tradition.

From based his theory of character upon his understanding of human nature. Character was a function of the self. Through his

42 Ibid, 134. His discussion of "Selfishness, Self-Love, and Self-Interest" runs fron 119- 141.

43/bid, , 121-24, 143.

44 lbld., .225 
involvenent in the social process man tried to satisfy the needs of the self and acquired his character. In Mon for Hiase/f From explained character as arising because of the self's need for relatedness. He mentioned the other four needs for transcendence, rootedness, unity, and devotion but in a context that suggested he considered then to be subsuned in a general need for relatedness. 45 "The fundamental basis of character," he argued, is seen in how "man related hinself to the world." A person's character described how he was related to the world, and From described this as a "character orientation." A single character orientation involved two processes of relating to the world. A process of assinilation determined an indiuidual's relationshlp to the naterial vorld, and a process of socialization his relationship to other people and with hinself. From out lined five character orientations. In turn, he outlined five processes of assinilation and five processes of socialization. Thus he defined each character orientation by its processes of assiailation and socialization. He further distinguished each of the five character orientations as being either nonproductive or productive. There vere four nonproduct ive orientations and one productive orientation. Honproductive and productive were synonymous ith unhealthy and healthy. Nonproductive orientations were unheal thy because they were perversions of hunan nature. In all because there vere four nonproduct lue character orientations, there vere four nonproduct lue 
processes of assinilation and four nonproductive processes of socialization. In addition because there was one productive character orientation, there was one productive process of assiailation and one productive process of socialization. I will begin with the four nonproductive character orientat lons, discussing first their processes of assinilation and then their processes of socialization. This will prepare the way for understanding the product ive orientation.

From's scheme began with a detailed analysis of the elements comprising the four nonproductive orientations. The four nonproductive processes of assinilation were the receptlue, exploitative, hoarding, and arketing. A receptive person felt that the source of all good was outside of hinself. He looked to others for nurture. Knowledge was something others gave hin, as was love. Decisions sere things others nade for him. He was typically "optiaistic and friendly," and he had "a certain confldence in life and its gifts." He functioned mell until his "source of supply is threatened. 46

The explaitative person was like the receptive in one respect. He saw the outside world as the source of all good. He did not however expect to be showered with gifts. His not to was "stolen fruits are sueetest." He appropriated the thoughts, love, and wares of other. 4 ?

46 Ibid., 62-3.
47 ibid., 64-65. 
The hoarding person unlike the receptive and the exploitative saw the outside world not as the source of good but as where bad things lurk. They were iserly and possessive of love. He valued order and security. His belleved that "there is nothing new under the sun," and "wine is wine and yours is yours." 48

In historical terms the receptlue orientation was nost prevalent in pre-capitalist, highly-structured, traditional cultures in which deference to authority was highly valued. In nodern cultures it revealed itself in peoples' attitudes towards "experts" and "public opinion". People respected the person who could tell then wat to eat, what to wear, and how to be happier. The exploitative and hoarding orientations referred to the prototypical capitalists of the oighteenth and ninetsenth centuries. They existed "side by side," the former as the ruthless freemarketer and the latter as his are conservative puritan counterpart. 49

The last, and most modern, nonproductive orientation was the marketing character. He was a protege of Dale Carnegie and had learned how to in frlends and influence people. He was a product of the modern abstract and impersonal marketplace. His orientation was "rooted in the experience of himself as a comodity and of his value as an exchange value." He was an individual with a plastic ldentity and his motto " 1 an as you desire ne." For him equality meant sameness, and peculior and

48 ibid., 66-67.

49lbid., 79-81. 
queer carried wholly negat ive connotations. His human relationships were superficial and his love, casual.

The four nonproductive processes of socialization were sadisn, nasochisn, destructiveness, and indifference or autonat on conformity

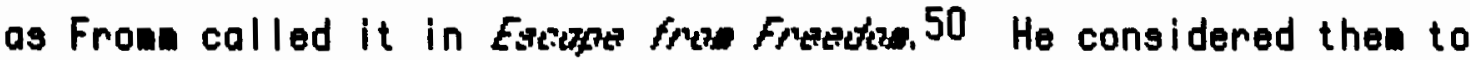
be "mechanisms of escape," and he distinguished then as either types of symbiotic relatedness on types of withdrawl-destructiveness. 51 Sadisn and masochism were symbiotic, and destructiveness and indifference were ithdrawl-destructive. The psychological meaning of symbiosis was "the union of one individual self with another." "Both the masochistic and the sadistic strivings," Fromm urote, "tend to help the individual escape his unbearable feeling of aloneness and powerlessness." 52 Though they had the same source, a fear of froedan, masochisn and sadisn were considered opposite expressions of the same striving. The masochist's perversion was the "conscious and intentional enjoyment of pain or husiliation." 53 His need to submit made him willing to suffer almost any abasement. The masochist was dependent on his tormentor, but From argued that

50 in Eacope tras Freedan From discussed a "mechanisn of escape," authoritarianism, which encompassed sadism and masochism, destructiveness, and automat on conformity. In Man for Hinsedf he changed the name of "automaton conformity" to "Indifference." In addition, he elaborated upon these and discussed four nonproductive processes of soclalization. The analysis in the two books was essentlally the same; however, in the former he went into greater detall, his motluation being Hitler and Hazl Germany.

51 Frann, Man for H/aself, 107.

52Frome, Escoupe trou Freedon, 151.

53 ibid, 148. 
the tormentor, the sadist was also dependent on his victim. 54 A sense of his own isolation and power lessness compelled the sadist to seek a sense belongingness and importance through donination. Sadisn and masochisn were alternative manifestations of the same "symbiotic conplex," and From preferred to speak of the sadomasochist ic orientation, 55

In Escope fram Frocutan From used his analysis of the sadomasochlstic orientation to explain the rise of Nazisn in Gernany during the 1930s. Hazisn, he clained, appealed to psychic needs of those dissat lofied ith their declining fortunes in the post Horld Har I era. He explained Hitler's appeal to the German lower widdle class, the petit bourgeois, on the grounds that its status nas nost threatened by econonic upheaval, 56

Destructiveness and indifference led to withdrawal rather than symbiosis. Sadisn was destructive, but the goal of sadisn was the incorporation of the object. The destructive orientation, however, ained at its elimination. From explained, "Sadisn tends to strengthen the atomized individual by the dosination over others; destructiveness by the absence of any threat fron the outside. "5? The destructive person wants to be left alone by the world. When the world, intruded he lashed out. The automaton or indifferent as plastic. He gave up his individual self and became an autonaton,

$$
\begin{aligned}
& 54 \text { lbid., } 145 . \\
& 55 \text { lbld., 158-59. } \\
& 56 \text { lbid., 216-17. } \\
& 57 \text { lbld., } 179 .
\end{aligned}
$$


"identical with willions of others," and had no need to "feel alone and anxious anymore. $" 58$

The processes of assiailation and socialization were associated. People tended to respond to things and people in sinllar ways. The narketing orlentat lon was conpatible with autonat on conformity, the receptive orientation with masochisn, the exploitative orlentation with sadisn, and the hoarding orlentation with destructiveness. 59 In From's eyes modern man was beconing an outonation, and his character was being conditioned in the marketplaces of goods and services(people) and of ideas. From described modern an in teras of his "pseudo character, "pseudoacts," and lastly, "pseudo-self."60 Since man, according to From, "acquires that character which nakes him want to do what he has to do , the pseudo condition of modern man's existence presupposed that sodern soclety was a pseudo soclety. The fate of the sane society and the fate of the productive orientation were inextricably linked. Until there was a sane society, From did not belleve that there can be truly sane people. The living by definition were insane.

The indictment of the mental health of individuals was an indictment of the mental health of soclety and vice versa. In the sane Saciety he declared that "The cure of social pathology must follow the same principles [as the cure for individual pathology],

58 Ibid., 186.

59From, Man far Hisself, see diagran on 111.

60From, Escupe tros Freedon, 185-206. 
since it is the pathology of so many human beings, and not of an entity beyond or apart from individuals." 61 Thus the cure of individual pathology and disappearance of nonproduct ive characters waited on a social metanorphosis. The productive orientation was a complete contrast to the four nonproductive ones. Its process of assivilation was "working," and its process of socialization was "loving and reasoning."62 The productive person did not see the outside world as elther the source of all good or all bad. He related to the world and to people on the basis true self-interest and true self-love. Self-interest and self-love entailed the same thing for all individuals because they arose out of man's existential condition. From urote,

Human exlstence is characterized by the fact that man is alone and separated from the world; not being able to stand the separation, he ls lapelled to seek for relatedness and oneness. There are many ways in whlch he can realize thls need, but only one in which he, as a unique entity, resains intact; only one in which his powers unfold in the process of being related. . , 63

Frome's vision of a world of love and reason, of harmony, of the brotherhood of man, is one whose beauty few would dispute. He offered some guidelines in the sone saciety for going about the restructuring of human existence. 64 Basically, he called upon man

61From, the sime siniety, 273.

62From, than for Hinself, 110-11.

63/bid., 96-?.

64 /bld., Chapter 8. 
to put into practice the principles nost people already paid "lip service" to-- fairness, equality, and respect.

Faith was the key to understanding Fromn's utopianism. He descrlbed faith as a character trait. The word for faith in the old Testament was "Enunah," and From translated it as "firmess." 65 Faith as a confident attitude to From. In the Jevish tradition faith was expressed by a confident attitude in man's relation to God. For the sodern age when belief in God was no longer sustainable, From folt that faith in mankind mas indispensable. He argued that his religious humanisn was the logical successor to the Judeo-Christian belief in God. "There is much less difference," he urote,

between a mystic faith in God and an atheist's rational faith in mankind than between the former's faith and that of a Caluinist whose faith in God is rooted in the conulction of his oun powerlessness and in his feor of God's power, 66

The heart of the atter was Frome's faith in the regenerative capacity of man. Frome's argunent with his critics such as Scharr, who favored the orthodox position of Freud, 67 was in the tradition of the centuries old debate over the nature of an and sin. Centuries before, Pelagius and August ine had argued over the nature of Rdan's sin and its meaning for humanity. Rugustine mas Judged the inner and Pelaglus a heretic for his rejection of the idea of original sin. From sided with Pelagius. "The battle was won by

65!bid, 199.

66/bid., 210.

67Scharr, Escape fros Autharity, 79. 
Augustine," he wrote, "and this victory was to determine--and to darken--man's mind for centuries." 68 In the end--despite his popularity--Froma's view was not representative of the intellectual climate of the 1940s and 50s. He could contrast himself to Reinhold Niebuhr whose brand of "neo-orthodox" Christianity gained proninence in this period.69 On the one hand, Miebuhr was less pessiaistic about the present and on the other hand, less opt imistic about future. Man, for Niebuhr, had a paradoxical nature, possessing both a capacity for evil and a capacity for good. He did not see evil, as From did, as a secondary potentiality. Niebuhr warned against humanistic conceptlons of man and argued that the "root of sin" was man's overestination of himself, hubris. "Sin," he wrote in foith and History, 'is, in short, the consequence of man's inclination to usurp the prerogative of God [and] to think more highly of himself that he ought to.,. "70 He reproved utoplans lacking of caution and exulting the powers of man, and he viewed utopian thought as a recipe for tragedy. In the aftermath of World War II the mood was cautious, and Niebuhr was a principal evoker of it. Fromm's optinisa about human nature and confidence in the future stood out as a more hopeful prophecy. But it stood out in another respect, as well.

68from, Hon for himedt, 211.

69lbid., 212, note 6?. Also see Richard Wrightman Fox, Beishalot Miebuhm (Hew York: Pantheon Books, 1985). Fox believes that Niebuhr was "much closer in spirit" to Freud's Ciwllizatian ano Its Discontents than to Froan's Man for Hisself, 256.

70Reinhold Hiebuhr, Foith and History (Hew York: Scribner's, 1949), 121. 
There was a dourness to From's thought. At the outset I enphasized the tension between optimisn and pessisisn present in Froms's work. There was a uluid contrast between lightness and darkness in his thinking. On the one hand it seens as though his aind was burled in the present, and on the other as though it was in full flight to future. The present, refracted through visions of death everywhere, as apparently beyond redenption. "In the nineteenth century," Froman mote, "the problen was that God is dead; in the twentieth century the problem is that man is dead." Pl The twin perils were "war and robotisn." Yet by an act of human ill the present would give way to the future.

The noral problem of the twent ieth century, From wrote, "is man's indifference to himself," 72 The choice to do good was man's, and he cont inued:

Heither the good nor the euil outcome is autonatic or preordained. The decision rests ith man. It rests upon his ability to take hiaself, his life and happiness seriously; on his illingness to face soclety's moral problen. It rests upon his courage to be himself and to be for hinself. 73

It is not clear, however, that an can choose to do good. Perhaps, only individuals can. I wonder whether the moral position of each individual is linked, as suggested by Froma, with that of all other men? Hhat If the moral fallures of soclety were only reflections of the moral foilures of Indlulduals? Did he not know any sane or

71From, the sane society, 360.

T2/bid, 248.

73lbid., 250. 
moral men. What, for that natter, about Erich Frome Certainly, he was not indifferent to the fate of man. From used the study of character to find man, all men, innocent. He shifted the blane for war and genocide from Hitler and his henchmen to the social pressures that nolded their characters. From nust have hated a world that could generate such evil, yet he loved man and aade plans for his future and tonorrow's better world.

In chapter two we turn to the work of David Riesman. In his work the concept of social character becane less fatalistic. He used the study of character to address a different problen. Whereas From focused on the problem of evil, Riesman was concerned with individualisa. He celebrated the autononous individual tho transcended his socially prescribed character. His concern for individualisn was not unrelated to events that influenced the tenor of Fromes sork. The rise of totalitarianisn brought to the fore anong American intellectuals worries about the forces of centralization and bureaucratization in American life. John Scharr has renarked that David Riesnan took "the iddle fron Fromm" but "refused both Froma's presises about the human condition and his whole critical position. "74 Here Scharr nicely captures the general relationship between Riesman's thought and Fromn's. Fromm's psychology provided Riesman ith a way of explaining the American character. Rissman admired From, but try as he wight he was 
unconfortable with Fromes view of man and did not subscribe to his utopianisn.

* $\quad$ *




\section{CHAPTER 111}

\section{DRUID RIESMRM}

Durlng the 1940s and 50s the dangers of polltical and economle agglomeration In the United States seened unparalleled. A host of books detailing the plight of modern bureaucratic man appeared. Hriters such as HIIIlan H. Whyte, C. Hright Mllls, Dulght Macdonald, Paul Goodman, and Dauid Riesman focused their at tent lon on the problens of the individual in mass soclety. Rlesman's mork stands out for lts theoretlcal analysis of character and hlstorlcal perspective.

Aiesnan approached the problem of indiuldualism from a sociological point of ulew. The central question of sociology is how the actions of people in a soclety are coordinated. Aiesnan adapted the study of character and addressed this question. Character, as it was dofined by From, functloned as a coordinating mechanisn. The indiuldual, he wrote, "acquires that character which nakes hle want to do what he has to do." 1 Thus, according to Fromn's theory of character, soclal coordinat lon was achleved through the psychological Indoctrination of Indiulduals. By their very natures sociological analysis and the study of character raised

IErich Fromn, Man for Hissalf (How York: Rinehart \& Company Inc., 1941), 60 . 
questions about individualisn, in particular about its validity as a concept? The key question for Riessan, in this respect, was if individuals acquire the character that sakes then want to do what they have to do, how can people be sald to express thenselves as individuals?

Riesman's concept of autonony addressed the problen of individualisa from within the study of character. Autonony was one of three "modes of adaption." Modes of adaption expressed in teras of character how a person reacted to the socialization process. For Riesman a person could be anomic, adjusted, or autononous. Riesnan believed that the majority were either anowic (maladjusted) or adjusted (normal). Most were adjusted. A sinority was autononous, and they were heroic to Riesman. Despite the fact that Riesman's discussion of autonomy cane towards the end of The Lane/g Crowt, it was the key to understanding his theory of character. The concept of autonony, in a sense though, stood above his analysis of character because the person who was autononous represented an exception. He us unique and did not share ith others the character of his time. To fully appreciate the importance of autonony in Riesman's thought, it is first necessary to underst and its place in his theory of character. Therefore, 1 ill discuss autonony now only in general terms and return to it later when 1 have laid out enough of his theory of character.

The autononous defied characterological analysis. Riesman considered the achievenent of autonomy to be an awakening to the reality of social conforsity. The autonomous person was someone 
whose "acceptance of social and political authority was always conditional," someone tho could "cooperate with others in action wile maintaining the right to private judgement." 2 He was someone who coordinated his own actions rather than had his actions coordinated for him. Thus for Riesman the study of character becane one of assessing social pressures toward conformity. This suggests, of course, that he sau knowledge of then as their renedy, that he saw understanding of social character as first step toward autonony. Riesman's historical study of character, The Lane/y Grurad, can be understood in light of his individualisa. The object of his study was to gain a better understanding of the nodern setting by placing it in its historical perspective, that is to gauge the chances for autonony in modern feserica against those in provious periads.

Riesman's enphasis upon individualism signaled the Americanization of Fromes study of character. Fromn's focus was on the relationship between wan and society. Riesman, however, zeroed in on the relationship between the individual and society. His concern for individualisn placed him within a honored tradition in American letters. "The quest for the autonomous individual," Joseph Gusfield has uritten, "absorbed American social coment from Enerson to Riesman." 3 The Lanely chowd throughout reninds one of Emerson's

20avid Aiesman, The Lane/y Crowd, abridged edition with a 1969 preface (Hew Haven: Yale University Press, 1950; Yale University Press, 1953), 251.

3Joseph Gusfleld, "The Soclologlcal Reallty of Amerlca," an Making Ansmicans. Essays in honar of Dawid flestan ed., Herbert Gans, Mathan Glazer, Joseph Gusfleld, and Christopher Jencks (University of Pennsyluania Press, 1979), 52-3. 
dictun in "Self-Reliance:" "It is easy in the world to live after the worid's opinion; it is easy in solitude to live ofter our oan; but the great man is he who, in the nidst of a croud, keeps with perfect sweetness the independence of solitude." 4 Like Emerson Riesman worried about the degree to which society linited individual inagination, thought, and action. Thus he was led to consider how individuals could free thenselves of their socially prescribed character. He was much less prone than From to confuse the dest iny of a single individual with the fate of humanity. Riesman held out hope for an autononous ninority in an otherwise "insane society." Though he patterned his autononous character on Fromn's "product ive orientation," he found it "hard to imagine an autononous society coming into being now, even on a small scale, or perhaps especially on a small scale." 5 He considered the autononous few to be the "saving remant" of humanity. By their refusal to succumb to isolation and helplessness they showed that it was possible, even in the nodern bureaucratic age, to llue with "vitality and happiness."

Riesman, himself, has led a life of vitality and happiness. He wos born in 1909 in Philadelphla where he grew up in well-to-do Jewish household. His fewinist mother cane from a prowinent fanlly, and his father was a respected physician. He studied chenistry at

4Ralph Haldo Emerson, "Self-Rellance," Esartyst, First and

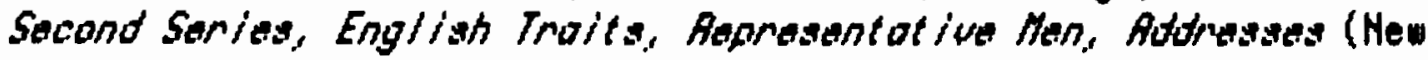
York: Hearst International Library Co., 1914), 36.

5Dovid Riesman, "The Souing Rennant," Individurlise Acacansidened and athen Esutugs: (New York: The Free Press, 1954), 116-20. 
Harvard and then awitched to law. He clerked for Just ice Brandeis and subsequently taught law at the University of Buffalo. It was not unt il 1946, when he joined the faculty at the University of Chicago, that he began the career in sociology that ultimately secured him a place in the intellectual history of the twent leth century. He was at Yale briefly during wich tine he wrote the Lase/y Craws, and today at nearly eighty he teaches at Haruard. Perhaps through all of this he has demonstrated the control over his oun life characteristic of the autonosous man he championed. His colleague Peter Rose has described his in paradoxical terms as a "pro-Enlightenment, ant i-Progressive, German-Jewish Philadelphia gent leman, Haruard don, and self-proclaimed autonomous man. "6 His biography gives the impression of man sho "rejected the map in order to grope his own way." Riesman described a person who chose to "grope his own way" as a "narginal figure," as someone who was unconfortable sat isfying the expectations of others when they conflicted with his own.?

In one of his earliest articles Riesman described his attitude toward life as an "intransigent refusal to bow to the inevitable." 8 He believed that life involued each individual in a struggle to realize and saintain autonony. In no real sense were any of us born

GDavid 1. Rose, "David Riesman Reconsidered," Streita(y) March/April 1982, 53.

PDavid Riesman, "Marginality, Conforaity, and Insight," Individualisa Reconsidered and ather Essugs, 166-78.

ODauld Riesnan, "The New Soclety," The Rt fantils, January 1939, 96-?. 
free. At birth each of us Inherited a way of life ith accepted standards of thought and behavior. Riesnan argued that freedom was potentially ours, and he was certain that each individual had the capacity for uniqueness. He felt that

the enormous potentiallities for diversity in nature's bounty and men's capacity to different iate their experience can become valued by the indluidual himself, so that he will not be tempted and coerced into adjustment or, falling adjustment into anomie. The idea that men are created free and equal is both true and isleading: men are created different; they lose their social freedom and the ir individual autonony in seeking to becone like each other, 9

Riesman sensed that the cost of autonomy was too great for most people to bare. Exceptional individuals such as Bertrand Russell served as examples of what was possible. 10 Society, hosever, acted to discourage autonony through iaposing social character on individuals. Fee could resist the pressures to conform to the dictates of society, friends, and family, and even fewer could rebel successfully. Like Canus's rebel, Rlesman's autononous man insisted "on a right not to be oppressed beyond the linit that he [could] tolerate."ll The individual, hiesman argued, must retain the right to say no. "His acceptance of social and political

9hiesman, the Lane/y crowd, 307.

1ORiesman mentions Russell in the Lane/y crowe and in a number other places as an outstanding example of an autononous individual. Anyone familiar with Russell's career can understand why.

11Albert Camus, The fehel, A revised and coaplete translation of L'Hoase fewo/te by Anthony Bower (New York: Uintage Books, 1956), 13. 
authority، " Riesnan declared, "is always conditional."12 He possessed what he termed the "nerue of failure," "the courage to face aloneness and the possibility of defeat in one's personal life or one's work without being morally destroyed."13 The "nerue of failure" represented a recurring theme in Riesman's mork, and it meant simply the capacity to endure rejection by one's peers.

The relationship between Riesnan and Fromn's thought was complex. Riesman adnired from and was inclined to view his utopianisn sympathetically. In "Some obseruations on Comunity Plans and Utopia (1947), "he declared that "a revival of the tradition of utopian thinking seens to me one of the important intellectual tasks of today." He defined a utopia as a non-existing but potential reality. It was rational in contrast to an ideology which was wholly irrational and, therefore, not a potential reality. Utopian thought, he orote, was difficult and rare: "Fen scholars achieve the kind of sensitive and friendly relation in reality ohich is necessary for utopian creation--a relation in which one respects 'what is' but includes in it also 'what night be', "14

Though the terns ideology and utopia were borrowed from Karl

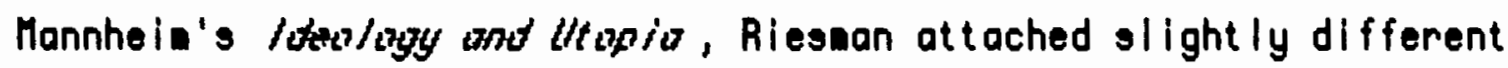
meanings to then. Riesman noted that he was true to Mannhein's idea of their "dialectical opposition," but Mannhein had characterized

12 Riesman, The Lonely Crowd, 251.

130avid Riesman, "R Philosophy for Minority Living," Individualise Becansidered, 55.

140avid Rlesnan, "Some Observations on Community Plans and Utopio," Individualise Beconsidered, 75-77. 
both ideology and utopia as irrational belief systens. For Mannhein, a zealous comitment to preserve the past was the heart of ideology, and o fervent desire for change was at the center of utopia. Between ideology and utopia mas reality. The understanding of reality as a task for the sociology of knowledge. The sociology of knowledge aimed at soluing the problem described by Mannhein as "the social conditioning of knowledge" through a sort of synthesis of ideology and utopia.15

Riesman, to the contrary, saw Fromm as a utopian not in Mannheis's critical sense but in the sense that From was able to see "what is," "what ought to be," and also "what can be." Though he spoke of From as a "more hopeful prophet" 16 and drew upon Froma's "productive orientation" for his concept of autonomy, Riesman's understanding of autonomy, in contrast to Fromm's, rested on an assumption that the conditioning of individuals could be overcone. Riesman explained,

The power of individuals to shape their own character by their oun selection among models and experiences was adumbrated in our concept of autonony; when this occurs, men may limit the prouinclality of being born to a particular fanlly in a particular place. To some, this offers a prospect only of

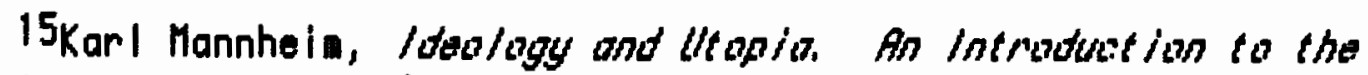
Saclalogy of knowledge (New York: Harcourt, Brace and Company, 1952), chapter iv and $v$. Also, The Encyclopedic af Fhilasuphy, 1972 ed., s.v. "Mannhein, Karl," by Werner Stark.

16David Riesman, "The Lonely Crowd: A Reconsideration in 1960," The Sociallagy of Culture and the Anolyats of Souriol Charocter; The wark af Axidt fileanun flewiewsed, ed, by Seymour Mart in Lipset and Leo Lowenthal (New York: The Free Press, 1962), 458. 
rootless men and galloping anomie. To sore hopeful prophets, ties based on conscious relatedness nay some day replace those of blood and soil, 17

Rlesman was working in an age in which the fallures of Marxist and socialist utopias weighed heavily on the ainds of intellectuals. The menace of totalitarianise was real for then. Hitler's Germany and Stalin's Russia were not distant nenories, but contenporary events. As Richard Pells has argued, Riesnan mas genulnely anbivalent about utopian solutions in general: "[his] attack on conforaity contained radical iaplications fron which [he] drew back because the one alternative [he] could inagine--socialisn--seened responsible for the very collectivist attitudes they condenned. "18 Riesnan understood well the bleak history of utopias although he was convinced that without utopian thinking, ithout wat he saw as realistic visions for the future, history mould essentially stall. In a sense Riesman saw utopian thought as the notive force of history. "The status quo," he orote, "proves the nost illusory of goals." Aiesman was interested In utopias as blue prints for the future, not messianic reveries. A utopian conception was "timelocated in the future." It was a hypothesis, a conception of a "social order which has not yet been tried, though it is a realistic possibility, not a nere idle drean." He considered utopias to be rightful clains of the living for a better world.19

17ibid., 458,

18Richard Polls, The Liberal Mind in a Cansenwotive Hge (How York: Horper, 1985), 248.

19Riesman, "Some Observations on Community Plans and Utopia," Individualise Reconsidered, 70. 
In The Limsely Cramd, Riesman's most important work, he inplored his readers to "realize that each life is an emergency that only happens once." 20 while his thesis in the Lane/y cromod had to do with a changing American character, his larger theme was the plight of individuals in the modern era. This theme was exemplified in his concept of autonomy.

Aiesman's belief in autonomy recalled Alexis de Tocqueuille. Aiesman felt that the modern American "wlllingly takes up with low desires without daring to embark on lofty enterprises, of which he scarcely dreans." 21 In fact, Riesman's entire study of the American character harkened back to Tocqueullle and his classic study of the

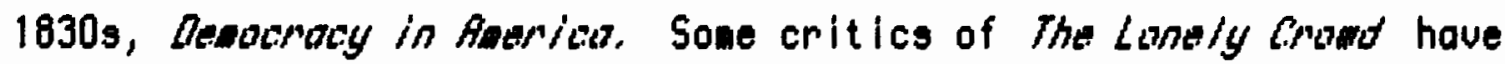
used Tocqueville to dispute Riesman's thesis of a changing American character. Some have argued that Riesman and Tocqueville not only asked many of the same questions but al so gave many of the same angwers. Fron the start Riesman was wll aware of his Tocqueuilleian dilema:

It is my impression that the iddle-class American of today is decisively different from those Americans of Tocqueville's writing who nevertheless strike us as so contemporary, and wuch of thls book 111 be devoted to discussing these differences. 22 ,

With his theory of soclal character Rlesman explored the

20David Biesman, the Lonely Crowd, 297.

21 Riesman, Tha Lanaly Concud, 235. See also Alexis de Tocqueville, Desocracy in America, ed., J.P. Mayer (Garden City, Hew York: Anchor Books, 1969), 632.

22/bid., 15. 
rolationship between how peoplo live and who they ore. Riesman was most interested in Americans, although he believed that his theory was more idely applicable. He essentially tried to connect changes in how Americans llued to changes in who Americans were. No one disputed the fact that in the century after Tocqueville first described the equalitarianise of Anglo-Americans, great social, econonic, and political changes had taken place which would have made American soclety unfamiliar to the Frenchman. Hould the American people also have been unfanlliar to Tocqueville? This was the questioned raised by Riesman. His answer made hin fanous. Riesman's argument in the Lane/y frowd ran a simple course. First, he took the differences between the id-ninet eenth century America and mid-twentieth century Rmerica to be self-evident. Second, he assuned that there sas something called social character. Third, he defined social character as a product of the design or conditions of society. Suggesting that social character had naterial basis, Riesman drew upon Erik H. Erikson and clained that social character sat isfied "the largest needs" of society and was a result of "econonic-historic necessities." 23 for hin, fromm had shown that types of character existed out of soclal necessity. "In order that any society may function well," Riesman quoted, "its menbers nust acquire the kind of character which nakes then want to

23/bid., 5, citing Erik H. Erikson, "Obseruations on the Yurok: Childhood and Horld lage," Lniversity of Colifornio Fublications in American Ancheology and Ethnalogy, XXXU (1943), iv. 
act in the way they have to act as members of society. "24 Fourth, Riesman basically reasoned that since society had changed, society's needs sust have changed, and, furthermore, that since society's needs determined social character, social character must also have changed. Riesnan in essence turned Max Weber on his head by suggesting that the work ethic as a consequence not of ideology but of denographic and econowic conditions.

In The Lane/y Crawd Riesnan identified three types of character, "tradition-direction," "inner-direction," and "otherdirection." The three character types described three processes of socialization which, Riesman argued, corresponded to three stages of historical development. Riesman called them "modes of conformity." Each distinguished a historical relationship between individuals and society, that is between the character of individuals and society:

Thus the link between character and society--certainly not the only one, but one of the most significant, and the one 1 choose to emphasize in this discussion-- is to be in the way in which soclety ensures sone degree of conformity from the individuals who make it up. 25

Each character type corresponded in theory to a perlod of history. Riesman identified these three historical epoches in terms of stages on a population $S$ curve. He proposed a causal relationship between changes in population and changes in character:

I tentatively seek to link certain social and characterological 24 /bid., 5, citing Erich From, "Indiuidual and Social Origins of Meurosis," Baericon Souralagical Fewiam, It (1944), 380. 25lbid., 5. 
developnents, as cause and effect, ith certain population shifts in Hestern society since the Middle Rges. 26

High birth rates and death rates characterized socletles at the base of the curve which mere in the first stages of development. Such societies had what Riesman called "high growth potential." They were highly stable, tradition-directed societles. Inner-directed societies on the widdle level of the $S$ were said to be in a stage of "transitional growth," that is to say they had high birth rates but declining death rates. Consequently, inner-directed societies had burgeoning populations. Societies entered the final stage on the top of the $S$ when birth rates began to taper off suggesting, Riesman said, "incipient population decline."

There was a close relationship between the denographic and econonic characteristics of societies. The inclusion of econonic factors in his analysis deserves added enphasis because subsequent to The Lamely Conerd Riesman abandoned his population thesis and revised his argunent. At that point his sork suggested an American character that resulted out of an interplay of ideology and economic enviroment. This argument, implicit in The Lasely Croned, David Potter later developed in The fecsole of flonty. In The Lanely Cranot Riesman believed that "it would be almost as sat isfactory" for him to categorize societies according to their stages of econonic development as the economist Colin Clark had done by dist inguishing anong "primary," "secondary, " and "tert iary" econonic systems. 27

26 ibid., ?.
27 ibid., 9. 
For exanple, in a society with "high growth potential," a traditiondirected society, people were occupied with the innediate problen of group survival so they hunted, fished, farmed, and ined. During the phase of "transitional grouth" and of inner-direction they became involved in production in order to satisfy the demands of a growing population. During the phase of "Incipient decline" and other-direction people worked in trade, communication, and consunption. Because production levels renain high, denand had too be stimulated. Thus Riesman identified the development of a consunption-oriented society as the crucial factor in the transition fron inner-direction to other-direction. Riesman believed that there was a historical pattern to how societies insured conformity which he linked to population levels. Rccordingly,

each of these three different phases on the population curve appears to be occupied by a society that enforces conformity and molds social character in a different way. 28

Riesman's concepts of tradition-direction, inner-direction, and other-direction reflected the manner in which a society insured that its menbers were responsive to the needs of the group. Each explained a method by wich a society coordinated the actions of its nembers. In a tradition-directed society, change occurred very slowly and children learned that things were as they had always been and aluays would be. In short, they learned to value social and cultural norms because they perceived then to have an existence over and above individuals. In contrast, an inner-directed society uas 
marked by rapid change, and children internalized a set of core values that enabled then to function in an ever changing environaent. Riesnan likened the function of these values to a "gyroscope," in that they served to keep children balanced and on course. Children learned to value hard work, achievenent, and thrift so that they would be able to survive in a conpet it ive world, a world of scarcity. In an other-directed society, however, survival becane less difficult. Scarcity was overcone. People needed to work less in order to feed, cloth, and house thenselves and had more time to spend socially. Fashion arose to displace culture as the regulat or of lifestyles. The other-directed confronted problens of a new sort. With nore social tine interpersonal problens became more common: "Increasingly, other people are the problem, not the the material enviroment." 29

People found themselves needing to know how to get with along other people, A "radar screen" replaced their "gyroscope." No longer single-minded in the ir pursult of econonic sastery, individuals needed to be sensitive to all the stimuli of their social enviroment. The "ecarcity psychology" of inner-direction had given way to an "abundance psychology." For Riesman this explained in terms of character the difference between America in the nineteenth century and America idway through the twent ieth century. America, according to Riesman, was soving toward what Willian $H$. White called a "social ethic" as opposed to a now 
outdated "Protestant work ethic." Rs Riesman stated In the flrst paragraph of the Lasely Craws:

This is a book about social character and about the differences in the social character between different regions, eras, and groups. . More particularly, it is about the way In which one kind of social character, which dominated America in the nineteenth century, is being replaced by a social character of quite a different sort. 30

While The Lane/y Cnowot was primarily a study of the development of other-direction in America, Rlesman contended that it was applicable to man in general. "My analysis of the otherdirected character," he urote, "is thus at once an analysis of the Amerlcan and of contemporary man. "31 The general intent of his argument flowed from the causal nature of hls population thesis which should have been broadly appllcable. There were problens with this thesis, which others qulckly pointed out. Oscar Handlin argued that the population explosion in the eighteenth century century occurred after the characterist lcs of inner-direction were already establlshed. 32 Also, the population thesis did not explaln why the United States was ahead of Britain and France in the development of other-direction. Both of those nations, one would lagine, reached the stage of "Inclplent- population decllne" before the Unlted States. 33 Furthermore, there was tension between Riesman's concern

30 lbid., 3.

31 lbid., 19.

320scar Handlin, "Toward a Personal Autonony," The Saterrotizy Seviee of Literuture, 3 March 1951, 14.

330avid Potter, The Feaple af flenty (Chicago: University of Chicago Press, 1954), 61. 
for autonony and his population thesis. Could individuals really hope to alter the course of "economic-hlstorlc necessit les?"

Riesman eventually changed his ind about the link he "tentatively" established between shifting population and changing character structure. For example, in a "reconsideration" oritten in 1960, he clained that he had not been "suggest ing that the shape of a population pyranid caused a particular social character to energe."34 Clearly, however, he had so argued and afterwards, in light of criticisn, altered his position. He went on to say that he had given "far too little place to persistent American values and their inpact on the soclal character, "35 Rleswan was responding to directly to criticisas made by Seymour Lipset in "A changing American Character?" 36 Lipset had argued that Americans in the teent ieth century subscribed to the sane values as Americans in the nineteenth century and that this continuity in values inplied continuity in character. While Riesman dropped his population thesis, he maintained that his perception of change was valid. By contrasting Riesman with his critics we sharpen our view of him. Three of his wore prominent critics were the historian Carl Degler, the sociologist Seynour Lipset, and the anthropologist Clyde Kluckhohn. They rejected Riesman's perception of change and argued

34David Riesman, "The Lonely Croud: A Reconsideration in 1960," Culture and Sasial Charactar, 422.

35 lbid., 422.

36Seynour Mart in Lipset, "A Changing Amerlcan Character?" culture and scocial chorocten, 136-171. Lipset subsequently developed his orgument nore fully in the First Haw Hot ian (New York: finchor Books, 1963). 
instead that the American character had shown remarkable stability. Degler, for instance, argued that the evidence led to a conclusion opposite of the one Biesman drew:

There ay be some accentuation of certain aspects of it in our the, but wat Tocqueville designated in the 1830 s as "democratie" is essentially what Riesman means by other direction. Rather than a changing American character, the evidence suggests a remarkably stable one, at least since the early years of the nineteenth century. 37

What Degler said was tantamount to argulng that there was a difference between Americans of the nineteenth and twent ieth centuries but not enough of one to constitute a change in character. It was as though he concelued of the American character as an invilolate hand-me-down passed from generation to generation. Degler's position suggested that the character of a people had no relationshlp to external condltions, that IIfe could change but people would not.

Clyde Kluckhohn made a similar assessment of the status of Amerlcan character when he suggested that Amerlcans had matured since Tocqueullle's day. Kluckhohn further ventured that the differences that existed between the present and past were exaggerated In the 1950 s because of stressful world conditlons:

The changes in American values during the past generation are in part consequences of processes steadily affecting all "advanced" industrial societies, in part the result of more temporary political and economic currents playing upon the

37Carl Degler, "Sociologist As Historian," Amanlaun Histary and the Social Soiences (Hew York: The Free Press, 1964), 519-530. 
whole world. 38

Both Degler's and Kluckhohn's arguments seemed to be that, while the strength of the American inclination toward mediocrity and conformism was stronger than ever, it was still the same inclination, and, therefore a change in character had not occurred. Their position denied the possibility of change on the basis of sisilarities between generatlons. The change identified by Riesman did not discount similarity.

In the Finst Mew Mot ian Lipset tried to explain the uniqueness of the United States as a consequence of the persistence of certain values. He argued that the commitment of the American people to two basic values has been sustained for over a century and that these values had influenced the course of the material and technological change that Riesman suggested had altered the American character. Lipset was clearly truer to the idealist position of Max Weber, something he pointed out and Riesman acknowledged in the "reconsideration." The two values that Lipset pointed out were "achievement" and "equality," and he argued that the dialectical tension between them had defined the course of American history. "Both strands," he wrote, "the equalitarian and the achlevementorlented, remain strong, but changing conditions somet imes fortify one at the expense of the other, or alter the internal content of each." 39

38Clyde Kluckhohn, "Have There Been Discernable Shifts in American Ualues during the Past Generation," The Alerviam Sty/e (Hew York: Harper, 1958), 145-217. 39Lipset, The Finet Hew Nation, 147. 
In Lipset what Riesman called other-direction was really an indication of equalitarianism holding sway. Lipset claimed that other-direction was "an epiphenomenon of the American equalitarian ethos." 40 Lipset's analysis, however, was vague and the American comitment to the values he identifled inconstant, suggest ing that the fortunes of ethos of achlevement and the ethos of equality seened to be related to the material and technological conditions that Lipset wanted to deemphasize. The polnt is that Lipset unintentionally buttressed Riesman's case. What Riesman described os a shift in character, Lipset called a shift in value onphasis. Perhaps this difference was explained by the fact that Lipset was not disheartened by the rising tide of other-directedness. He agreed with Kluckhohn, who wrote,

Today's kind of "conformity" nay actually be a step toward more genuine individuality in the United States. "Conformity" is less of a personal and psychological problen--less tinged with anxlety and gullt, , . If someone accepts outwardly the convent ions of one's group, one say have greater psychic energy to develop and fulfill one's private potentialities as a unique person. 41

In contrast to Kluckhohn and Lipset, Riesman clearly was worried by the fact that people did not seen to aind being indistinguishable from others, and it was the attitude that saw conformism as a good thing that he thought was indicative of the new age and the modern character. Hillian H. Whyte similarly identified

40 lbid., 150.

41 lbid,, 158. Also Kluckholn, "Have there been Discernable Shifts. . . "The Aserican Style, 187. 
this difference as a new "social ethic." The chief point of Riesman's analysis of other-direction, however, was not that it was conforaist. He did not challenge outright Tocqueville's characterization of denocratic people. He thought that the tendencies Tocqueville had keenly observed had becone "the nore aut onat ic outcone of a character structure governed, not only from the first but throughout life, by signals from the outside." 42 There as a difference between those having the same internalized values and acting so as to get along and prosper and those not really having values and being regulated by the "cues" of others. Correctly, Riesman did not belleve that Tocqueville was inplying other-direction. Also, it has to be remenbered that Tocqueville was oriting with an eye to the future of France so his descriptions of America were at the same time extrapolations of it. This helps to explain, I think, the apparent tineleseness of Meacorary in Amenicar. What Riessan noted about the other-directed person was his at titude toward himself and life. As opposed to the inner-directed, he was content aerely to get along. Riesman wrote,

They [the other-directed] are not eager to develop talents that wight bring then into conflict; whereas the innerdirected young person tended to push hlaself to the llialt of his talents and beyond, 43

The material anbitions of the inner-directed nay not have been lofty, as Tocqueville thought, but they vere anbitions all the same. In conclusion, Riesman's character types vere not as distinct as

42Riessan, The Lane/y Crowd, 256.

43Lipset, The First How Hotion, 234. 
some critlcs have suggested. Change was gradual, and it was not dramatic, and, Riesman could have said, easily overlooked. The change in character, Riesnan inplied and Potter eventually argued, hinged on the development of the United States into a consumer society. Inner-direction and other-direction were different but not opposites. Both were the appropriate characters for the nature of their time and place in history. Neither were autononous. Autonony described only one way--for that matter, Riesman argued, an exceptional way--in which people may adapt to society. In all there were three "mode of adaption" which Riessan said were universal types. According to how a person adapted to society, he was either anonic, adjusted, or autononous. Like "nodes of conformity" "modes of adaption" were descriptive. Used together Riesmon uas able to describe society and the relationships individuals have ith society. For instance, in the nineteenth century a typically inner-directed person was adjusted. In 1950 an inner-directed person was likely characterologically untypical and, therefore, anowic, meaning he did not have a character appropriate for his time and place. Riesman explained the relationship between nodes of adaption and character structure succ inctly:

The "adjusted" are those whon for the nost part we have been describing. They are the typical tradition-directed, innerdirected, or other-directed people--those who respond in their character structure to the demands of their soclety or soclal class at its particular stage on the curve of population. Such people fit the culture as though they were made for it, 
as in fact they are. 44

In his general understanding of the relationship between society and individuals Rlesman added nothing to Fromm's theory. Though his typologies were original, Riesman saw Individuals in terms of their character as products of soclety. Adjusted individuals, he said, were "made" for society. Since they were not making themselves, society must be making them. Soclety, itself, was an "econonic-historic" necessity, and Riesman suggested that he could locate a society's relative historical position by its denographic traits.

Rut onony was, however, the hopeful exception to this vieupoint. An autonomous person was not typical in his character. He was not tradition-directed, inner-directed, or other-directed according to the nor in a society. He was a character type all his own, not a historical type. He resenbled the anomic: "For autonomy, like anomic is a deviation from adjusted patterns, though a deviation controlled in its range and meaning by the existence of those patterns [of other direction and inner-direction]." 45 But, unlike the anomic, the autonomous represented the possible transcendence of place and time in terms of character. For the autonomous conformity was always selective and tentative. Thus in the 1950s the autononous could appear at times to be other-directed, in concert with society, and at others at odds with it. "HIs acceptance of social and political authority," Riesnan urote, "is always

44Riesnan, The Lasely Crume, 242.

45 lbid., 249. 
conditional. .46

The anomic, adjusted, and autonomous were possible during any of the three historical periods. Riesman belleved that there was little chance for autonony in traditional societies because they were so static. Riesman actually felt that the greatest possibilitles for autonony were in modern, other-directed societles because affluence peraltted people with the opportunity to change directions and adopt new lifestyles. He cautioned, however, that "the very fact that his (the autonomous person's) efforts at aut onomy are taken as cues by 'others' nust make him consclous of the possibility that the effort toward autonony ingt degenerate into other-directed play-acting. "47 The possibllity for "otherdirected play-acting" may explain why countercultures in the sixties turned into rigid communities.

There was tension between Fromn's concept social character and Riesman's hopes for autonony. Riesman's concept ion of personal aut onony was not shared by From. To Riesman, while the influence of socioeconomic conditions may be extremely powerful, they could not be deterninative in Fromn's sense. The difficulty existed, perhaps, because he was persuaded of the usefulness of the methodology of Fromion social paychology and the adroitness of its descriptions while at the same time he clung to his individualistic beliefs.

Riesman stressed the roles of utoplan thinking and of autonomous

46/bid., 260.

47lbid., 258. 
characters in history. His emphasis on ideas and individual action was incompatible with the Fromaian concept of social character. It was possible to inagine the necessity of a particular social character to have been de facto, not de jure. It was something to wich people surrendered. Riesnan suggested that this was the proper interpretation when he referred to "the power of individuals to shape their own character," and it was why the idea of aut onony may be rightly understood to represent a fourth, though indeterminate and non historical, character type. Fromm, however, had explicitly cautioned against this approach when he stated "that the relationship between society and the individual is not simply in the sense that cultural patterns and social institutions 'influence' the individual." Riesman's interest in the individual was not shared by Fromm, and the mixture of Fromm's concept of social character with Riesman's concept of autonomy was awkward.

I noted earlier Joseph Gusfield's belief that Riesman's concern for autonony sounded a traditional theme of American letters. The concept of autonony ran counter to the trend in modern social science by positing what Gusfield called a non-sociological self. 48 The sociological conception of man, according to Gusfield, discounted the individual and viewed a person as a "group product," "class character," and "institutional role." 49 Clearly Froma's theory of character rested upon the assumption of a sociological

48Gusfield, "The Sociological Reality of America," an Making Anaricans, 52-3. 49 lbid., 52. 
self. Thus when Riesman drew upon Frome's study of character he sixed two contradictory perceptlons of man, one soclological and the other non-sociological.

There is a venerable history to the thought that inforas the soclological vieu of man including the likes of Marx and Durkhein. Marx ay have done more than anyone to shape this conception. "It is not the consciousness of man that deternines their existence," he orote, "but, on the contrary, their social being that deteraines their consciousness. "50 Historical man for Marx was no more than a reflection of a class role in society, itself a consequence of "naterial productive forces." He and Engels discussed ideas as "the phantons formed in the human brain [which] are also, necessarily, sublinities of the naterial life-processes, which are enpirically verifiable and bound to material prenises." 51

In the twilight of the nineteenth century Durkhein published his study of suicide as a "social fact." He descrlbed suicide as a social phenomenon linked to a pathological (abnormal) condition of society. 52 Durkheim argued that increasing suicide rates in his day were tied to rising levels of egoisn and anowie, conditions resulting from either a lack of integration into society or a breakdown of social norns that provide guidance. The foult lay in

50 lbid., 53.

51 Karl Marx and Frederick Engels, "The German Ideology," The Monx Englas Reoder (Now York: Nort on Books, 1978), 154-55.

52Gusfield, "The Soclological Reality of America," 53. Also Robert Alan Jones, Enile Rurkhein (Beverly Hills: Sage Publications, 1986), chapter 4. 
the failure of society's inst itutions to integrate or guide individuals satisfactorily. The point is that Durkheis, like Marx, saw individual fates as consequences of objective social and historical realities. Gusfield has called this development in sociological thought "the objectification of society, " a viev of society that assumes a social organization exists which is real and has "the power to move levers that shape. . . events." 53

Froms concept of social character assuned that socioecononic forces predominated in the formation of personality. Riesman's concept of autonony, however, protested against this ingrained sociological view of man. From Riesman's perspective the existence of an identifiable social character testified to the weakness of most men. Riesman was skeptical about the chances for achieving autonony, but he believed autonony from the pressures of society was possible. The concept of autonony was the vital difference between Riesman and Fromm. It arose because they had different concerns. Riesman focused on the relationship between individuals and society while From enphasized the relationship between man and society. In From's thought social character became the key for understanding the regeneration of man. The transformation of man was to follow upon the transformation of society as though a city designed for angels would necessarily house angels. Man was sick because society was sick. There was no room in Fromm's world for the exceptional because no one transcended his socloeconomic condition. From

53Gusfield, "The Sociological Reality of America," 53. 
vanted to exonerate man from responsibility for the evil in the world. Therefore, the possibility that man wight be autononous of society could not be. The exception counted nost for Riesnan. He denied Froms's prenise and conclusion for the sake of individualisn. Ironically, he ended using Froms's egalitarian concept of social character to establish the existence of great individuals. He postulated a non-sociological self for the cruclal very few.

Without the burden of its population thesis Riesman's analysis offered an intriguing view of the Raerican character. He indicated that the change from other-direction to inner-direction vas clearly involued with the development of a consunption oriented society in America. Because Riesman's analysis ended up being specifically about the Rmerican character, his work suggested the existence of a unique American identity. The idea of "Rserican exceptionalism" interested historians in the 1950s. Taking his cue from Riesman, David Potter inquired into the origins of the modern Rerican character. 
CHAPTER IU

\section{DAUID POTTER}

In 1950 The Halgreen Foundat lon Inulted the hlstorlan Dauld Potter to wrlte a serles of lectures on the Influence of American economlc abundance on the American character. When he began hls research, he dlscovered that the work of a vast number of anthropologists, psychologlsts, and soclologists was related to his proposed study of the American character. I in his work he acknowledged the Influence of several these "behauloral sclent ists," most notably Margaret Mead, Karen Horney, and Dauld Riesman. The last of these, Dauld Riesman, had the greatest influence on Potter's study of the Amerlcan character, The Feaple of flenty. For Potter, Riesman showed how the development of the American character was connected to the development of a consumption-orlented society. "One of Rlesman's chlef contrlbutlons," Potter wrote, "Is In tracing the effects of the change from an enuiroment that not luated the Individual as producer to one the motluates him as consumer." 2 Potter belleved that Rlesman's population thes/s had conpllicated the watter of understanding the economlc factor In the American

Touid Potter, The Feople of Flenty (Chicago: University of Chicago Press, 1954), vil.

2 lbid., 5 ? 
character, and he proposed to explain producerism and consunerisn as expressions of American abundance at different stages of development. Thus Potter's made explicit a thesis left laplicit in The Lasenty crand.

Hith regards to thls thesls Potter can be seen as a logical successor to Riesman in the same manner that Riesman's work followed logically from Frona's. Like Riesnan, as well as Froma, personal considerations underlay Potter's Interest in the study of nat lonal character. Fromen's notivation stenned from his experience with evil--the rise of Hitler and the decline of Germany. Riesman, a champion of individualisn, used study of character to assess the fortunes of his individualistic ethos in the nodern bureaucraticcorporate clinate. Potter was concerned with his identity as an American. A Southerner born in 1910 in Augusta Georgia, Potter was sensitive about his southern identity, as well as a proud American, in a the when patriotisn was a great concern in Reerica. During the years of the Second Horld Har and the Cold Har he was driven by a desire to understand, and integrate, his Southern and Aaerican identities. When he died in 1971, his colleagues' in "A Memorial Resolution" aptly described hl as a "native Southerner who transcended his southern heritage but never disclaimed it. . . ."3

Potter's specialty was southern history and the Cluil Har. Through his work he tried to show that there was no contradiction to

3Don E. Fehrenbacher, Howard A. Lanar, and $0 t$ is $A$. Pease, "David M. Potter: A Menorial Resolution," The durengl af Anerricun History, Septenber 1971, 301-10. 
being both a Southerner and an American. He did not think that the two identities had been ant ipathetic prior the Civil Har, nor after it. He argued that the war between the states had not been an "irrepressible conflict" between divergent cultures, but rather the result of conflicting interests. This was the basis for his challenge to the historiography of the Civil War and its aftermath. In addition to the disunion of North and South, he insisted, the historian of the Civil Har had to explain their reunion. Too often, he held, the historian's discussion of secession overlooked the restoration of national sovereignty from 1865-1900.4 He argued that the dissolution of the Union did not imply any basic incompatibility between South and Morth. In fact, he naintained that the NorthSouth split occurred in spite of their growing "homogeneity, "and that the restoration of the Union was swift and easy because of this. "Once the mistaken assumption of mutual exclusiveness is accepted," he urote,

the false conclusion follows that sectional distinctiveness can serve as an index of deviation, and by the sane token that loyalty to the section can becone an index of disloyalty to the union. 5

In Potter's work the cultural factor and the role of interest were not unrelated, but the fact renained that "within an integrated culture acute conflicts of interest ay be generated, and between

"David Potter, "The Hature of Southernian," The Sweth and the Sectianol Canflict (Baton Rouge: Loulsiana State University Press, 1968), 76-78.

5lbid., 78. 
diverse cultures strong comunity of interests nay develop. "6 By explaining the origins of the Cluil Har in a context of conflicting interest and not as an "irrepressible conflict "between ways of life, understanding reunion after the defeat of the South became less of a problen for Potter. It is clear that his observations about the Civil Har were not unrelated to his concern for the study of the American character. He saw the Civil Har as a war between Americans, and for him, a southern American, understanding the American character--Southern as well as Horthern--held special significance.

Anericans, according to Potter, were a people of plenty. The thesis of the feople of fleniy was that economic abundance--plenty-had conditioned the American character. He devoted nost of the book to developing this thesis. The book also addressed a methodological point. He believed that the study of national character had to be interdiaciplinary, and he hoped to bridge the gap between history and the behavioral sciences-- psychology, soclology, and anthropology. The behavioral sciences, he believed, grounded the study of national character on theories of human and social development. Hithout the behavioral sciences history lacked "any weans for analysis of the chief factor wh thich hlstory deals," namely man.? History offered an understanding of the conditions for change. Thus Potter argued that

\footnotetext{
Glbid., 79.

Tlbid., xii.
} 
history can learn wuch about the nature of man and society from the behauloral sciences; the behavioral sciences can learn much about the 'external forces lapinging upon man,' and about the nature of social change, fron history. $\theta$

He felt that as a historian he could contribute to understanding of the larger economic forces that influenced the development of the Anerican character. The fecsple of flenty, then, analyzed the transition of society in the United States from a production orientation to a consumer orientation--in David Riesnan's terminology from inner-direction to other-direction. 9

Potter drew upon the behavioral sciences to explain the meaning of national character. 10 He followed the "neo-Freudian" line of thinking developed in the work of From, Karen Horney, Abram Kardiner, Ralph Linton and others. It is helpful to recall the discussion of Erlch Frana's theory of character in chapter one because his definition of character helped to shape Potter's: Potter drew directly upon From's point that

in order that any soclety may function mell, its members nust acquire the kind of character which makes them want to act in the way they have to act as members of the society or of a special class within it. They have to desire what objectively is necessary for then to do. Outer force is to be replaced by inner compulsion and by the particular kind of human energy which is channeled into character traits.11

Blbid., xul. Potter was discussing and quoting fron Caroline Hare's the Cultural Aparoush to Histary (1949).

9lbid., 59, 69-70.

10lbid., 32-72.

11/bid., 11. This was material that From incorporated in Man for Hiseelf (Hew York: Rinehort \& Company, Inc., 1947). On page 60 of Mon for Himself From makes the same point. 
Furthermore, From defined personality as "the totality of inherited and acquired psychic qualities which are characteristic of one individual and which make the individual unique." What Potter proposed for the subject of national character studies was that part of personality From had said was composed of acquired psychic qualities. For Potter, like From and Riesman, distinguishing between man's biological heredity and his social heredity was crucial. Social psychology forged a link between the study of personality and the study of society by revising (or rejecting) Freud's biologisn. Culture was "the mediun" and personality "the receptor."12 The rather sensible asestion that how we live affected how we responded to the world led to the assertion that people who shared a way of life should respond in similar ways to the world, suggesting the existence of a "basic personality structure."

Potter was inpressed by the linking of personality to socialization in the anthropological studies of people such as Ruth Benedict and Margaret Mead. To Potter the development of "culture and personality analysis," a synthesis between the flelds of psychology and anthropology, was one of the "eplc advances of modern social acience."13 In the United States "culture and personality analyeis" had opened new doors to the study of the American character. Thus, for example, Potter accepted Rlesman's placenent of the Inner-directed and other-directed character types in American
12 Ibid., 37.
13/bid., 37. 
history and did not try to devise his own character types. Hs we shall see, Potter felt that Riesman did not explain the reasons ahy the era of inner-direction had given way to the era of otherdirection. In fact, he argued that "culture and personality analysis" conducted solely fron the perspective of behavioral scientists failed to understand causal factors behind changes in character.

Potter belleved the concept of abundance could explain why the character of a twent ieth century American differed from the character of a nineteenth century American. In societies of scarcity and moderate abundance, Potter argued, "the social imperative has fallen upon increases in production" because societies have either an insufficient or a barely sufficient supply of goods to sat isfy extant desires. But in a society of abundance, production of goods outpaced consunption and therefore consunption had to be stimulated. "The nost critical point in the functioning of society," he argued, "shifts from production to consumption, and, as it does, the culture nust be reorlented to convert the producer's culture into a consuner's culture."14 According to Potter when producers acquired capabilities in excess of demand the historical relationship between supply and desand reversed itself: "the linitation has shifted to the market, and it is selling capacity which controls his [producers] grouth."

19/bid., 173. 
The feczole of flesty ended up more or less clarifying the historical context of the Lane/y Crowe by enphasizing the factor of abundance instead of population. Potter also tested his theory on Margaret Mead's and Karen Horney's analyses of the American character because he felt that they, along ith Riesman, painted the same portrait of modern Rmerican character. Potter used Mead and Horney along ith Riesnan to frase a synthetic description of the Aaerican character. "Drawing these three interpretations together," he concluded, ". We have three treatments which agree, or may be construed as agreeing, that the American character is in large measure a group of responses to an unusually conpetitive enuironment. " 15

Potter developed his synthesis along these lines: In Anot kep fous Fowdes Ary (Hew York, Hillian Morrow \& Co., 1942) Mead argued that the American character was geored toward the achievement of success, not status. In the drive for success a prenium was placed upon mobility and change. Since success was measured against the past, success, itself, represented a break with the past. People could no longer resort to the traditional ways of doing things--for Instance ralsing children--so Instead they looked to their peers for guidance. Mead understood pressure toward conforaity as a consequence of a success oriented society. She suggested that the innigrant origins of the American population explained the Rmerican character. She deacribed faericans as behaving like third-

15/bid., 60. 
generation imsigrants. The first-generation imsigrant typically clung to traditional ways, the second rejected then consciously and tried to assinilate, and the third assinilated freely. In Potter's words the third generation American succeeded by "perfecting his conforaity to American ways and in winning the approbation of his noighbors." Potter bellioved that Mead's description of the American character was accurate, but he doubted wether her generational thesis could alone explain its development. 16

Riesman tried to place the sodern character in a historical context by linking changes in character with changing lovels of population. Potter faulted Riesman's population thesis because it did not explain why the French and English who, he belleved, had begun experiencing "Incipient population decline" nuch earller than the United States" were not the leaders in the characterological ovolution toward other-direction. And lastly, in The Necerof is: ferstersolity in Oern Fies, Karen Horney argued that there was a cultural basis for nourosis and that conpetitive societies bred rivalry, fear of others, and fear of failure. Her's was not a study of character at all, but an analysis representative of the "neoFreudian" approach which Potter found useful in establishing the Iink between personality and the social process. He could have used From to explain both the nature of social character and the social cause of neurosis.

16potter did not believe that Mead's theory held true for other imigrant populations, such as those in Quebec and Costa Rica, who did not appear to share the Anerican character. 
Potter believed that Mead, Riesman, and Horney shared common ground. The analysis of each, he suggested, enphasized "the effects of the spirit of competition." Competition, he argued, was inherent to the "success cult." If Rmerican culture and character were success-oriented, as Mead argued, then competition must figure prominently in Raerican society. "Mobility, he averred, "says that the conpetitive race shall have no finishing post [and] conforaity requires the individual to show his belief in the conpetitive system not only by eabracing its goal but also by eabracing all the physical impedimenta and behavior codes. . . "17 Potter was a perceptive reader of Riesman. He realized that Inner-direction and other-direction were not 180 degree opposites and that both were competitive orientations. One pursued econonic gain wile the other went after social success. Potter wrote,

In an earlier tiae, when wost men worked for themselues and were concerned with subduing the environment, the traits of the innerdirected san--stanina, deteraination, unreaitting industry-- were at a prealum in competition. But in a soclety where the majority now work for others, where seruice bulks large in the economy, and where wealth is gained nore readily by manipulating other men than by further raids upon nature, the traits of popularity, persuasiveness, at tractiveness--"personality," as it is called-have become essential competitive equipment, and the 'otherdirected' man has forged to the front, 18

Hoting that Horney's analysis of nodern neurosis was prenised upon the deleterious effects of competition, Potter arrived at his synthetic statement about the nature of the American character. To

17ibid, 59.

18/tid., 59. 
repeat, Potter folt that the Anerican character was "in large neasure a group of responses to an unusually competitive environment."

Potter folt that the agreement among Mead, Riesman, and Horney about the nature of the Rmerican character justifled his undertaking a study of the American character and defined an approach for his inquiry to take. He thought that there was a common denominator in the analyses of Mead, Riesman, and Horney. ". . It may be worthwile," he stated,

to consider as a determinant the factor of econonic abundance-not the abundance of locked-up natural resources to which man lacks the technological key but the abundance of usable goods produced from these resources-- which the people of the United States have possessed in far greater degree than any other national population. 19

Potter argued that the concept of abundance was well sulted to Mead's theory because the measure of advancement in Raerican soclety was econowic success. Hithout an expanding economy characteristic of a soclety of abundance, personal fallure, not success, would be the norm. For Horney, Potter clalmed that abundance explained the mot luation underlying the competitive drlue she found was a cause of mental Illness. "The entlcements of potentlal abundance, Potter sald, "tempt us to abandon the systen of status, wh its soclal bargain to trade opportunity for securlty, and then the absence of

19/bid., 6?. 
security sets up the anxieties which Horney regards as charact eristic. 20

Potter thought also that his abundance theory was implicit in Riesman's analysis. Potter noted correctly that Riesman associated inner-direction with a psychology of scarclty and other-direction - ith a psychology of abundance and showed how the transit lon from one character type to the other had paralleled econonic developments in the United States. "But once abundance is secured," Potter urote, "the scarcity psychology which was once so valuable no longer operates to the advantage of society, and the ideal individual develops the qualitles of the good consuner rather than those of the good producer. $" 21$

Rid of its demographic aspect, Riesman's analysis still differed from Potter's. Alesman's shifts in population were allied to shifts in levels of technology. While technological development was a factor for Potter in the creation of abundance, it was a function of what Potter called aptitude, which in combination with natural wealth produced abundance. Potter never explained the source of this aptitude though at one point he referred to the American people's "notorious addiction to hard work." By apt itude Potter nay have meant Heber's Protestant work ethic, but he was never specific. What is clear is that for hin aptitude, as a cultural factor, emphasized progress and success.

20 bid, 71 .

21 lbid., 70. 
Potter's abundance thesis recalled Frederick Jackson Turner's frontier thesis. Potter, however, saw Turner as a crude environmentallst and criticized his tendency to "dwell upon the primary or physical enviroment and upon such factors in it as geography, climate, and natural resources, to the neglect of manmade conditions that surround us." 22 Turner, according to Potter, a isconstrued the seaning of abundance by focusing too narrowly on a particular anifestation of it, the farmer's frontier. He explained,

If abundance is to be properly understood, it nust not be visualized in terms of a storehouse of fixed and universally recognized assets, reposing on shelves untll humanity, by a process of renoval, strlps the shelves bare. Rather, abundance resides in a serles of physical potentialities, which have never been inventoried at the sane value for any two cultures in the past and are not likely to seen of identical worth to different cultures in the future. 23

Put simply, Potter did not believe that Turner took sufficient notice of the expanding frontiers of science and industry--the bases for creating abundance.

Potter's position assumed that the environment was always potentially bountiful. How a people went about realizing this potential was of central importance. Potter interpreted Turner's thesis to mean that the frontiersmen pushed west, accept ing a temporary lowering of clullized standards and weakening of social institutions, for the sake of progress in the future. Life on the

$$
\begin{aligned}
& 22 \text { Ibid., } 23 . \\
& 23 \text { lbid, } 164 .
\end{aligned}
$$


frontier in turn stimulated individualisn, democracy, and nationalish. To survive the frontiersman had to be capable of selfreliance, but also in the long run he needed the assistance of the national government to extend clullization mestmard; denocracy more or less followed as a matter of course because men who sau thenselves as equals were inclined to favor denocracy over other forms of government. 24

There were fundamental problens, according to Potter, in Turner's thesis. First, industrialization and urbanization were prominent features of the American landscape long before the last western lands were settled. Second, If Turner was right about the role of the frontier in American history and Its significance to the American character then the end of the frontier signaled a revolution severing the past fron the present. Potter expanded the meaning of the frontier in order to nake Turner's thesis useful in explaining industrialization and urbanization in the nineteenth and twent leth centuries. As one frontier had given way, others had pisen to prominence. Potter argued that

by failing to recognize that the frontier was only one for in which America offered abundance, he [Turner] cut himself off from an insight into the fact that other forms of abundance had superseded the frontler oven before the supply of free land had been exhausted, with the result that it was not really the end of free land but rather the substitution of new forms of econonic activity which terminated the frontler phase of our history. 25

24/bid., 152-55.
25 lbid, 156. 
A belief in progress underlay both Potter's and Turner's frontier theses since it was for the sake of progress that the quest for frontiers takes place.26 The idea of progress was central to understanding how Potter understood abundance. He defined abundance as "partly a physical and partly a cultural manifestation." He felt that abundance resulted from the interaction of man with his environaent. "For America, he wrote, "from the eighteenth century to the twentieth century, the frontier was the focus of abundance, physically because the land there was virgin and culturally because the Anglo-Americans of that time were particularly apt at exploiting the new country. "2? For a tine the quest for progress took the form of western expansion, but over time mastery of the environment began to be realized through industrialization. Esesntially, however, agrarian expansion and industrial expansion were two sides of the sane coin:

But this change in focus itself perpetuated and reinforced the habits of fluidity, of mobility, of change, of the expectation of progress, whlch have been regarded as dist inct ive front ler traits. 28

It would seen that the habits of fluidity, nobility, and change would have been derivative of the drive for progress. Both the agrarian and industrial phases reflected the drive to transform "natural vealth" into tangible "social wealth." It was the "apt itude" of a people for transforming natural resources into

$26 / b / d,, 154-55$.

27/bid, 164.

28/bid., 165 
useable things that made abundance a reality. Thus, according to Potter,

it is safe to say that the American standard of llving is a resultant wuch less of natural resources than of the increase in capacity to produce and that this was the result, directly, of human endeavor--the ventures and struggles of the ploneer, the exertions of the workman, the Ingenulty of the Inventor, the drive of the enterpriser, and the economic efficlency of all kinds of Americans, who shared a notorious addiction to hard work. 29

Through ingenuity and hard work the American people created a secondary environment of enormous wealth. The first settlers in the new world obviously had requisite character traits for realizing the economic potential that abounded. The result of the interaction between the American people and their environment was manifest, but the consequences for the American people in this process was not so evident. What have been the specific affects of abundance on the American character? To understand how abundance shaped the American character, it was necessary to relate abundance to changes in social structure because Potter--like From and Aiesman--understood character as a function of society.

Potter accepted Froma's definition of the relat lonship between character and behavior. "In order that any society may function well," he quoted, "its nembers must acquire the kind of character which makes them want to act in a way they have to act as members of the society or of a special class within it." ficcordingly character should be defined as a social phenomenon. It followed then that the 
influence of abundance on character should be inferable from any changes that abundance had urought on the social structure.

Potter began assessing the influence of abundance on the American character by discussing the offect abundance had had upon American values, "the forming and strengthening of the American ideal and practice of equality." Abundance had enabled Americans to see equality in terme of opportunity and not condition. He Tocqueville had noted, there was an almost natural condition of equality in America. In fact, Tocqueville had believed this to be the most distinetive feature of American society. Opportunity abounded for everyone in the form of land. By associating equality -ith opportunity it became essentially synonymous with a conflicting value, liberty. Citing Riesman, Potter argued that both equality and liberty had cone to mean the "freedon to grasp opportunity. "30 "In short," Potter explained, "equality cane to mean in a major sense, parity in competition. Its value was as a means to advancement rather than as an asset in itself." 31 The importance of this, according to Potter, was that Americans had been confortable accepting great inequality while believing themselves faithful to the value equality. Americans had depended upon social noblility to fulfil their dreans for equality. Echoing Tocqueville, Potter went on to suggest that the success of denocracy in America could be at tributed to abundance:

30/bid., 92. See Dauid Riesman, "Equality and Social Structure," doumal of Letgal and folitical sociology, 1, 1942, 14. 31 lbid., 92. 
He [Tocqueville] meant that a boundless cont inent enabled then to fulfil the promise of mobility. Democracy made this promise, but the riches of North America fulfilled it; and our denocratic systen, which, like other systens, can survive only when its ideals are realized, suruived because an economic surplus was auallable to pay desocracy's pronissory notes, 32 Potter here argued that democracy had promlsed equality and that abundance had allowed for enough social mobility to sat isfy the demand for equality.

It is clear that Potter traced his concept of abundance back to Democnsiy in America. Tocqueville had warned that democratic peoples "want equality in freedon, and if they cannot have that they still want equality in slavery. "33 Tocqueville's warning, of course, was addressed to his European audlence. He had felt that democracy loomed In Europe's future, and he worrled that democracy there would create problens whlch Americans due to their circumstances had been fortunate to avold. The main circumstance that allowed American's to remain both free and equal was the natural endowment of North Amerlca. "Their fathers gave then a love of equality and Ilberty," Tocqueville had claimed, "but it was God who, by handing a limitless continent over them, gave then the means of long remaining equal and free." 34

32Ibid., 93. See Alexis de Tocqueville, Denoconory in Anopico, ed., J. P. Mayer (Hew York: Anchor Books, 1969), 279.

33. Alexis de Tocqueville, Remocrocy in America, 506. 34/bid., 279. Potter quotes this passage out of a different translation which he does not cite. 
To sun up: Potter's theory of abundance was an elaboration of two old ideas, Tocqueville's and Turner's. Potter engaged in sweeping generalization when he spoke of the American people as a people of plenty. The distribution of mealth in America had al ways been far fros equal. He acknowledged this but contended, nonetheless, that "America has had a greater measure of social equality and social cobility than any highly developed society in human history." 35 The exclusion of blacks and native Americans, for instance, did not deny for Potter the fact that opportunities for social advancement had existed for the majorlty of Americans, Tocqueuille's Anglo-Americans and subsequently other white nales. The existence of opportunity, according to Potter, became the basis in fact for the apocryphal claim that America nas a classless soclety. "The myth of equality," he wrote, "held that equality exists not merely as a potentiality in the nature of man but as a working actuality in the operation of American society--that advantages or handicaps are not really decisive and that every man is the architect of his own destiny."

Foremost, abundance enabled the najority of people to live confortably. Abundance allowed for "outward unifornity," that is it became possible for the physical differentials of traditional class distinctions to be abolished. "The factor of abundance," he said, ". . has constantly operated to equalize the overt differences between various classes and to eliminate the physical differences 
between then." 36 Thus Rmerican society had an aura of equality that was more fiction than fact.

In traditional class society, Potter believed, even the lowliest status, conferred membership in the community and a sense of the belonging upon the individual. Abundance, however, by elininating overt distinctions anong people burdened then with more galling covert distinctions. "Whereas the principle of status affirmed that a minor position may be worthy," he announced, "the principle of mobility, as many Americans have construed it, regards such a station both as the penalty for and the proof of personal failure, "37 thile Americans may unfairly view those who are out of work or employed in menial tasks as personal failures, it is far fron certain whether the bonds of comunity were ever tight enough to bestow dignity upon the serfs, peasants, and beggars of earlier times. It was really unnecessary to debate which condition has resulted in greater psychological danage, the hopelessness of the past or the false hopes of the present. A worse case does not make a bad one better. Potter observed that a balance needed to be struck between the principle of mobility and the principle of status. "Abundance," he concluded, "destroyed this bolance by naking a good standard of living available for any man, while perpetuating a low standard as usual for nost men. "38 More likely, abundance reversed the inbalance rather than destroyed the balance.

36Ibid, , 102.

37lbid, 105.

38/bid, 109. 
As had Rieswan, Potter linked the change in character from inner-direction to other-direction to the development of a consumer society. He argued that during the last quarter of the nineteenth century Rmerican society was speedily transformed itself from a production-oriented to a consumer-oriented society. Potter folt that the desires of consumers were irrational. In so far as our appetites are subject to manipulation by others, Potter was correct when he said that social effect of advertising has been even greater than its econonic effect. Hs he wrote,

If the econonic effect is to make the purchaser like what he buys, the social effect is, in a parallel but broader sense, to make the indluidual like what he gets--to enforce already existing attitudes, to diminish the range and variety of choices, and, in terms of abundance, to exalt the materialistic virtues of consumpt ion. 39

If Potter was right, the cholce that Americans were deprlued of by advertising was the choice to say no. He did not discuss at length the character orientation of a consumer soclety because it was unnecessary, the topic already having been covered anply by several uriters, in particular David Riesman, 40

The critical implications of Potter's analysis of the American character are obulous, though they seen to have been largely ignored. Richard Pells, volcing a commonly held vlew of Potter, has argued that his central message was that Americans could rest easy, that "America enjoyed a hlstorlc exemption from the ldeological and

39 Ibid, 188.

40 lbid., 172. 
class convulsions of Europe." 41 This incorrectly interprets Potter. He did not suggest that life in Anerica was without serious problems. Actually, he implied that social life in America was deteriorating. On close reading one cannot but conclude that the feczple af flenty demonstrated the $\mid l l$-effects of capitalism on the American character. One can fault Potter for not drawing his conclusion forcefully. He was hesitant about "attenpting to bring in a verdict on the free-enterprise system. " 42

In "The Roots of American Alienation," written in 1964, Potter did go further, expressing Durkheim-like concerns about the inplications of a consumer society. 43 He found a profound sense of alienation anong Americans and argued that the situation was worsening because the soil that nurtured int imate human contact had eroded. "Traditionally," he urote,

our society aintained this capacity so effectively that it was almost taken for granted, but from the profound social changes of the past century or more, one of the many problems that have emerged is the impairment of many of the social contexts within which human relationships were nurtured, and the resulting psychological isolation, or alienation, as it is called, of those who can no longer form adequate relationships. 44

41 Richard $\mathrm{Pell}$, The Libenal Hind in A Cansentert ive Age (Hew York: Harper \& Row, 1985), 149.

42 lbid., 88.

43David Potter, "The Roots of American Alienation, "Essurys of Dowiof M. Fatter (New York: Oxford University Press, 1973), 304-33. 44lbid., 306. 
Along these lines he identified three factors exacerbat ing alienation. All three, he said, were consequences of the machine econony and specialization. First, he believed that the pattern of social organization had changed. Primary groups which fostered meaningful personal relationships such as fanily, neighborhood, and church no longer played the important roles they once had. Second, he felt that economic concentration and interdependence had robbed work of the meaning it once held. Third, he argued that relationships had become rationalized, that is indirect and fragmented--in sun, depersonalized.

Potter held that Rmerican values of equalitarianism and individualis vere an important source of allenation because they inspired distrust of society. Hhile conservatives and liberals nay have defined differently the threat posed by society, they agreed that society was a menace to some rights of the individuals. "Thus all parties," he contended,

have joined in celebrating the individual, whether as a gogetting exponent of the free enterprise econoay or as dissenting exponent of inority rights. And accordingly all have distrusted the group. The llberal, in the tradltion of Rousseau, regarded society as a source of corruption, while man apart from society was innocent. The conservat lue regarded any heauy enphasis upon the velfare of the group as 'socialion' or 'collectivisn'"45

Potter, as historian and as student of the fmerican character, cared deeply for his country and its citizens. His work was neither an undue celebration nor a mindless criticisa, but, rather, a carefully 
constructed portrayal of the American people. Potter, like Riesman and Fromm, urote from a personal perspective. Horrled--horrifled in the case of Fromm--by what they saw in the world, all three sought answers for their troubled worlds. From hoped to sustain the stricken masses with a utopian vision. Riesman hoped to encourage the beleaguered individualist. And Potter hoped to draw the bonds of commity more tightly. With differing viens of the world, though sharing a method of analysis, these men together represent an enduring moment in the intellectual history of this century. 


\section{CHAPTER $U$}

\section{CONCLUSION}

The task of thls thesls has been to examine the study of nat lonal character through the work of the psychologlst Er/ch Fromn, the sociologist Dauld Rlesman, and the hlstorlan Douid Potter. I have tried to proulde a critlcal exegesis of the three thinkers and to relate them to one another by discussing the Interconnectlons in their thought. I began ith Froman's social psychological theory of character, turned to Riesman's theory of soclology, and ended with Potter's theory of American history. Each I argued had to be understood in the context of his time, a period of history narred by war, death canps, Hitler's natlonal socialism, and Stalln's comunish.

I began w ith Fronm because he proulded a theoretical structure from whlch it was posslble to approach Dauld Riesman's Ideas about the Amerlcan character. In turn Rlesman serued as a springboard to Potter, because Potter's work on the Rmerican character elaborated upon Rlesman's model.

Fromm, a German, Jewlsh enigrant, used psychology to reconcile hinself to a world he belleved was consuned by eull. A leader in the development of "neo-freudian" psychology, he trled to save the world ith psychology. His hatred of the world around him was 
coupled with a boundless faith in the goodness of man. The task of his theory of character was to explain the social origins of ouil and, thus, show his audience that it was possible for man to alter the course of history. Man would return to his natural, uncorrupt state, according to Fromm, when society was transformed into commity founded upon principles of love and fairness. Thus in Froma's thought there was a utopian theme joined to a method of analysis which explained the psychological bond of man to society.

Fromm's method of analysis proved useful to Riesman. The link between an and society was character, and through the concept of character the analysis of society becane a study of personality. Thus social analysis provided a model of the personality or character of a people. A concern different from Fromn's notivated Riesman's interest in the study of character. The fate of individualism in Cold Har Rmerica, not the fate of good in the world, worried Riesman most. Riesman developed the concept of aut onomy to address the problem of individualism. Rutonony suggested that it was possible for the individual to free himself of his socially prescribed character. To assess the chances for outonony he devised a historical nodel of the Rmerican character. Iaportantly, Riesman linked the transition period to economic developments. He associated the change from "inner-direction" to "other-direction" with the development of the United States into a consumer-oriented society.

David Potter, influenced by Riesman's study of the Rmerican character, elaborated upon the economic orientations of "inner- 
direction" and "other-direction." He proposed the thesis that the economic abundance of North America had influenced the development of a unique American identity. The then popular theme of "American exceptionalisn" ran through in his work. The concept of economic abundance harkened back to both Tocqueville and Turner whose works were viewed with renewed enthusias by scholars during the 1940s and 50 s.

The idea of "American exceptionalian," consclously cultivated by Potter, lay beneath the surface of Riesman's analysis of the American character, as well. While Riesman tried to associate the character of Americans w ith the character of other Hestern Europeans through his population thesis, The Lasty frowot really suggested the nature of "American exceptionalisn," as it was developed by Potter. In fact, the study of the American character proceeded upon an assumption of "American exceptionalisn." This, I think, helps to explain the short-lived popularity of such studies. By the late 1950s as American intellectuals began to rethink the politics of the Cold Har, they began to rethink also the idea of "American exceptionalism." Hriting in 1959, John Highan exclaimed,

In contrast [to progressive history] the new look of American history is strikingly conservative. More than at any other time before, historlans are dlscovering a placld, unexciting past. . . . As Tocqueullle did more than a century ago, today's historians are exhibiting a happyland, adventurous in manner but conservat lue in substance, and --above all-renarkably homogeneous. 1

JJohn Highan, "Homogenizing our History," Conesentory, February $1959,94$. 
The study of the American character as a casualty of the political controversies in the 1960s. Consciousness of blacks, other minorities, and women and their absence from theories and studies of national character made these studies offensive to many.

Highan, however, eventually muted his criticion. By 1970 he had decided that "the idea of an Anerican consensus enabled us to take seriously the concept of national character, which had been unjustly denigrated for several decades. "2 He was right, but still there seems to be little interest in the work of Potter and Rlesman on this score. Recently, Richard Wightman Fox has argued that a reappraisal of Potter's work is overdue. Fox, noting that Potter enphasized the ideological center of culture, suggested that at present historians pay too much attention to groups ithin society and overlook the "values ideas, and practices that all [these] social groups share in varying degrees, "3 He added that Potter tried to show that American culture was a process which "holds Americans together, even as it enforces a stark differentiation of status and weolth." 4 I think that Fox is right about Potter, and 1 an led to draw an ironical conclusion about American society and the American people. The heterogeneity of America is more apparent than real, and the appearance ay sten from the extrene homogeneity of the Americon ideology. The emphasis placed upon group identity may

2John Highan, Uniting Anerican Histary (Bloomington: Indiana University Press, 1970), 159.

3Richard Wightman Fox, "Public Culture and the Problem of Synthesis," The dournol af Ameniaun Histary, June 1987, 113.

4lbid., 113. 
well be an expression of Americon ideology. "Grouplen" nay well be how Americans grasp at Il berty and equality, how Americans grasp at opportunity. It wos, after all, Tocqueville's opinion that Anericans were predisposed to "groupism" and hod a special tolent in "the art of association." "hs soon as several Aserlcans have concelued o sentleent or on idea that they want to produce before the world," Tocqueville wrote, "they seek each other out, and when found, unite. .5

5Rlexls de Tocqueville, Deacorocy in Amariloo, ed., J.P. Mayer (Hew York: Anchor Books, 1969), 516. 


\section{AEFERENCES CITEO}

Canus, Albert. The Rebel. New York: Uintage Books, 1956.

Cohen, Hermann. Beouson and Hopes; Select ions from the dewish Urltings af Hersan Cathen, trans., Eva Jospe. New York: W.W. Horton \& Co., 1971.

Degler, Carl. "Sociologist As Historian," Aanerican Histary and the Sacial Sciences. New York: The Free Press, 1964.

Edwards, Paul, ed. The Enoyelopedio of Fhilasoophy. New York: Macaillan Publishing Co., Inc. \& The Free Press, 1967, S.U, "Psychology," by R.S. Peters and C. A. Mates.

S.v. "Mannheim, Karl, " by Werner Stark.

Emerson, Ralph Haldo. "Self-Reliance," Exsayse, First and Sectand

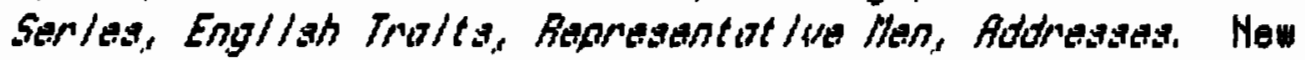
York: Hearst International Library Co., 1914.

Erikson, Erik H. "Observations on the Yorok: Childhood and World Image," liniverssity of California fubliatians in Alervian Ansthealogy and Ethnalagy, X8XU, 1943.

Fehrenbacher, Don E., Howard R. Lamar and Ot is A. Pease. "David M.

Potter: A Memorial Resolution," The doumat of Bmerican Histary, September 1971.

Fox, Richard WIghtman. Belnhald N/ebuhr. New York: Pantheon Books, 1985.

"Public Culture and the Problem of Synthesis," The slournal of American Histary, June 1987, 113.

Freud, Sigaund, Civilizatian and lta Gistantants. New York: $W . H$. Norton, 1969.

From, Erich, Escuge frase Freadom. New York: Rinehart \& Company Inc., 1941 .

"Indiuldual and Social Origins of Neurosis," Anerican Sacialogical Aewiem, 18, 1944.

Man Fan Hinself. Mew York: Rinehart \& Company Inc., 1947.

The Sane Society. New York: Rinehart \& Company Inc, 1955.

Funk, Ranier. Enizh Frogen: The Courage to be Humbn. New York: The Cont inuum Publishing Company, 1982. 
Gorer, Geoffrey. "National Character: Theory and Practice," The stcuty af Culture at a Distance, ed., Margaret Mead and Rhoda Metraux. Chicago: The University of Chicago Press, 1953.

Gusfield, Joseph. "The Sociological Reality of America," On Making

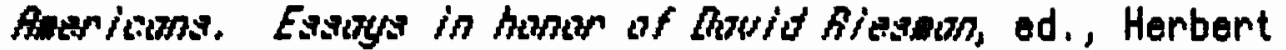
Gans, Mathan Glazer, Joseph Gusfield, and Christopher Jencks. University of Pennsyluania Press, 1979.

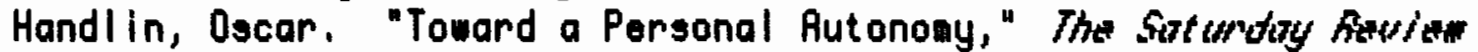
af Literature, March 3, 1951.

Highan, John. "Homogenizing Our History," Comentary. February 1959.

Writing Aweritan Histary. Bloomington: Indiana Universlty Press, 1970.

Hausdorff, Don. Erich Froms. Hew York: Twayne Publishers, 1972. Inkles, Alex and Daniel J. Levinson. "National Character: the Study of Modal Personality and Sociocultural Systems," The Handbaok of sacial Fuybralagy, 2nd ed., ed., Gardner Lindzey and Ell iot Aronson. Reading, Massachuset ts: Addison-Wesley, 1969.

Jones, Robert Alan. Esila Dunkteid. Beverly Hills: Sage Publications, 1986.

Kluckhohn, Clyde. "Have There Been Discernable Shifts in American Ualues during the Past Generation," The Alerviatz Sty/e. New York: Harper, 1958.

Lipset, Seymour Martin. "R Changing American Character?" The

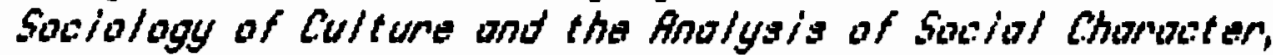
ed., Seymour Martin Lipset and Leo Lowenthal. Mew York: The Free Press, 1962.

The Flrat Mew Motlan. Hew York: Anchor Books, 1963. Maimonides, Moses. Guide of the Ferplexed, trans, M. Friedlander. Mew York: Hebrew Publishing Company, n.d.

Mannhein, Karl. Joblogy and Utopia. Hew York: Harcourt, Brace and Company, 1952.

Marx, Karl. Ear/y Uritings. Mew York: Uintage Books, 1975. Marx, Karl and Frederick Engles. "The German Ideology," The Marx. Eng/es Beader. Mew York: Nort on Books, 1978.

Mlebuhr, Relnhold, Falth and H/stary. Hew York: Scrlbner's, 1949. Pells, Richard. The Liberal Mind in a Canseruat ise Age. Hew York: Harper, 1985.

Potter, David. The Facole of Flenty. Chicago: The University of Chicago Press, 1954. 
"The Nature of Southernism," The South and the sectionul canflict. Baton Houge: Louisiana State University Press, 1968.

"The Roots of American Allenation," Essarys af Rowio $M$. Fotter. Hew York: Oxford University Press, 1973. Riesaan, David. "The New Society," The Atlantic. January 1939. The Lanely Crand: A storty af the Chunging Anerican Character. New Haven: Yale University Press, 1953.

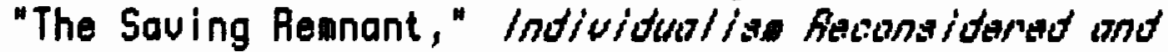
ather Essagss. New York: The Free Press, 1954.

"Marginality, Conformity, and Insight," Individuolisa fecansidered. . .

"Some Obseruat lons on Communlty Plans and Utopla," Individurlian feconsidered. . .

"The Lonely Crowd: A Heconsideration in 1960," The

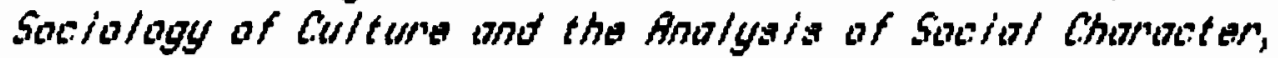
ed., Seynour Mart in Lipset and Leo Lowenthal. New York: The Free Press, 1962.

Rose, David I. "Dauid Rlesman Reconsidered," Satsiaty. March/April 1982.

Russell, Bertrand, A H/stong of Hestenn Philasaphy. New York:

Simon and Schuester, 1946.

Scharr, John. Escupe Fras Rutharity. Mew York: Basis Books Ine., 1961

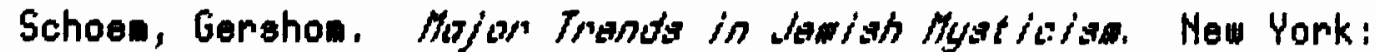

Schocken Books, 1954/5?.

Tauber, Bernard and Edward S. Landis, "On Erich Froma," In the Mase

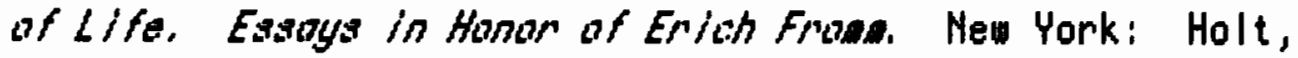
1971.

Tocqueville, Alexis de. Demaconey in Amerisa, ed., J.P. Mayer. Garden City, New York: Anchor Books, 1969. 